NBER WORKING PAPER SERIES

\title{
THE FEASIBILITY AND IMPORTANCE OF ADDING MEASURES OF ACTUAL EXPERIENCE TO CROSS-SECTIONAL DATA COLLECTION
}

\author{
Francine D. Blau \\ Lawrence M. Kahn \\ Working Paper 17241 \\ http://www.nber.org/papers/w17241
NATIONAL BUREAU OF ECONOMIC RESEARCH
1050 Massachusetts Avenue
Cambridge, MA 02138
July 2011

This is a revised version of a paper presented at the American Economic Association meetings, San Francisco, January 2009, the Cornell-Princeton Conference on the Princeton Data Improvement Initiative (PDII), Princeton, NJ, October 2008, and the PDII preconference, Amelia, FL, February 2007. The authors thank Orley Ashenfelter, Kevin Hallock, Lawrence Katz, Thomas Lemieux, participants at these conferences, and two anonymous referees for valuable comments and suggestions, Tecla Loup of the University of Michigan Survey Research Center for helpful information about the Panel Study of Income Dynamics, and Alan Krueger for help in preparing the PDII-Westat labor market survey data for analysis. We are grateful to the Princeton Data Improvement Initiative for funding this research. The views expressed herein are those of the authors and do not necessarily reflect the views of the National Bureau of Economic Research.

NBER working papers are circulated for discussion and comment purposes. They have not been peerreviewed or been subject to the review by the NBER Board of Directors that accompanies official NBER publications.

(C) 2011 by Francine D. Blau and Lawrence M. Kahn. All rights reserved. Short sections of text, not to exceed two paragraphs, may be quoted without explicit permission provided that full credit, including (C) notice, is given to the source. 
The Feasibility and Importance of Adding Measures of Actual Experience to Cross-Sectional Data Collection

Francine D. Blau and Lawrence M. Kahn

NBER Working Paper No. 17241

July 2011

JEL No. C81,J16,J24

\section{ABSTRACT}

We use Michigan Panel Study of Income Dynamics data and data from a 2008 telephone survey of adults conducted by Westat for the Princeton Data Improvement Initiative (PDII) to explore the importance and feasibility of adding retrospective questions about actual work experience to cross-sectional data sets. We demonstrate that having such actual experience data is important for analyzing women's post-school human capital accumulation, residual wage inequality, and the gender pay gap. Further, our PDII survey results show that it is feasible to collect actual experience data in cross-sectional telephone surveys like the March Current Population Survey annual supplement.

Francine D. Blau

ILR School

Cornell University

268 Ives Hall

Ithaca, New York 14853-3901

and NBER

fdb4@cornell.edu

Lawrence M. Kahn

ILR School

Cornell University

258 Ives Hall

Ithaca, NY 14853

lmk12@cornell.edu 


\section{Introduction}

Beginning with the work of Becker (1962) and Mincer (1962), economists have recognized the importance of work experience in analyzing the returns to post-school investments in human capital. Early research on human capital emphasized that on-the-job training can be as important a source of labor market skills as formal schooling. These skills can be learned through formal company-sponsored training programs or informally as workers learn by doing. Thus, any event that interrupts one’s career, such as childrearing, prolonged unemployment or labor force withdrawal due to discouragement, illness or injury, reduces one’s potential to acquire on-the-job skills.

The issue of workforce disruptions is likely to be particularly important for women because, under a traditional division of labor in the family, they are more likely to have taken time out of the labor force to bear and raise children. These choices can lead to gender differences in the extent of on-the-job training and thus contribute to the gender pay gap (Mincer and Polachek 1974). Moreover, perhaps anticipating intermittent labor market attachment, women may choose careers with fewer opportunities for on-the-job training and investment (Polachek 1981). Alternatively, or in addition, firms may anticipate such decisions by women and place them in jobs offering less training. And, through feedback effects, gender differences in treatment by firms (i.e., discrimination) can help to cause the traditional gender division of labor itself as well as to influence gender differences in the extent of on-the-job training and career choice. ${ }^{1}$ Moreover, since there is considerable variation in women's work histories, in addition to contributing to the gender pay gap, work force disruptions are likely to be important in analyzing female wage determination, particularly as female immigrants, who have lower

\footnotetext{
1 See, for example, Weiss and Gronau (1981) who point out the possibility of such feedback: “Thus, wage discrimination can affect not only the level of earnings but also the patterns of investment and earning growth through its effect on the length of career interruptions” (p. 609).
} 
labor force participation than native-born women (Blau, Kahn and Papps 2011), comprise a rising share of the female population. While workforce disruptions are likely to be a particular issue in analyzing women's labor market outcomes, some subgroups of men, for example blacks and the less educated, may experience disruptions to a greater extent than others. Declining relative labor force participation and employment rates for these groups relative to whites and the more educated suggests that variance in the work histories of men may be increasing. Moreover, with the aging of the population, it is becoming increasingly important to understand the process of retirement, including the degree to which workers choose phased retirement with partial labor force participation. Data on actual work histories are essential in studying this process. And with the growing share of the population born abroad, the study of work assimilation of immigrants is likely to become increasingly important as well. Finally, the length and depth of the Great Recession that began in December 2007 and ended in June 2009, ${ }^{2}$ the increase in longterm unemployment that accompanied it, and the anemic job recovery that followed ${ }^{3}$ have most likely made the issue of work experience disruptions of even broader significance across the labor force.

In addition to the importance of on-the-job experience for understanding gender differences in labor market outcomes, and wage determination for women and a number of other groups, it also plays a role in the study of wage inequality generally. Specifically, economists studying increasing wage dispersion in the United States and many other countries have focused on rising prices of human capital, including formal schooling as well as skills acquired on the job, as important causes of rising wage inequality (Katz and Murphy 1992; Juhn, Murphy and Pierce 1993). However, to correctly estimate the return to labor market experience requires accurate measures of labor market experience itself. ${ }^{4}$ And, differences across individuals in the

\footnotetext{
${ }^{2}$ These dates were determined by the Business Cycle Dating Committee of the National Bureau of Economic Research, see http://www.nber.org/cycles.html (accessed on July 14, 2011).

${ }^{3}$ See, for example, Center on Budget and Priorities, Chart Book: The Legacy of the Great Recession, see http://www.cbpp.org/cms/index.cfm?fa=view\&id=3252 (accessed on July 14, 2011).

${ }^{4}$ For example, when labor market experience is measured by an experience proxy, like potential experience (i.e., an estimate of the time elapsed since the individual left school), increasing actual experience for a given amount of
} 
extent of labor market experience are an example of the kind of population heterogeneity that can also affect observed wage inequality (Katz and Murphy 1992; Juhn, Murphy and Pierce 1993).

To analyze these issues, one needs data on individuals’ work histories. Yet the most representative and largest national data bases in the United States - the Census, the American Community Survey, and the Current Population Survey (CPS) do not collect information on actual work experience. This omission does not present a serious problem in measuring work experience for those who are continuously employed full time throughout their adult lives, as is the case for many groups of men. However for those with interruptions of full-time work experience, these data sources will lead to potentially serious measurement errors and thus biased estimates of the returns to experience as well as the quantity of post-school human capital investment. In addition, the lack of information on actual experience in these data bases also has serious consequences for analyzing differences in pay across groups, most notably, perhaps, the gender pay gap. For example, to the extent that women have substantial interruptions of their careers, using proxies for experience such as the estimated time since one left school (potential experience) will understate gender differences in labor market qualifications. Insights into intergroup differences in occupational choice and educational attainment will also be less complete than otherwise. Moreover, virtually all of the literature on wage inequality has used data such as the CPS and thus does not control for actual work experience. This may lead to biased estimates of the return to experience for some groups, and changes in the dispersion of actual work experience will be treated as a source of changing "residual” wage inequality-i.e., wage inequality that cannot be explained by observed skills or by the prices of observed skills. Therefore, in addition to helping us understand group differences in wages, data on actual work 
histories can lead to a more accurate accounting of the reasons for changes or differences in wage inequality. ${ }^{5}$

There are two national sources of data in which work history information is collected: the National Longitudinal Surveys (NLS) and the Michigan Panel Study of Income Dynamics (PSID). The NLS is focused on specific age cohorts and was never intended to be representative of the full US population. ${ }^{6}$ In contrast, the PSID was intended to be a representative sample of the US population in 1968, with a sample of 5000 families in that year. However, work history data have been collected in the PSID only among heads of households and wives, and the sample changes over time due to attrition and the addition of new members of the original households or their descendants. Thus, while the PSID does cover the entire working age range, its representativeness of the US population at any point in time depends on the characteristics of the attriters and the new members of the panel, as well as on whether heads and wives are representative of the total adult population. For example, the PSID does not collect detailed work histories of adult children living with their parents, if the parents are at the head of the PSID-defined family unit. In addition, the PSID allows for sample sizes of roughly 4,000-6,000 employed workers with wage observations in any given year. In contrast, the CPS is a random cross section each year, assuring representativeness, and is much larger than the PSID, admitting wage analysis samples of at least 30,000 in recent years. ${ }^{7}$ The larger size of the CPS allows one to stratify by subgroups including, by age, education, race, and ethnicity or nativity status.

In this paper, we use data from the PSID and from the Princeton Data Improvement Initiative (PDII) survey conducted by Westat and described at :

\footnotetext{
${ }^{5}$ As pointed out by Lemieux (2006), residual inequality itself can be affected by the distribution of observed worker attributes. Having data on actual work experience can inform analyses of the impact of observed skills on residual inequality as well as on overall wage inequality.

${ }^{6}$ For example, the original cohorts included men age 45-59 or 14-24 in 1966, and women age 14-24 or 30-44 in 1968.

${ }^{7}$ In previous work on gender (Blau and Kahn 1997 and 2006), we confirmed that the PSID and CPS yielded roughly similar conclusions about gender wage differentials and wage inequality over the 1979-1998 period. Of course, the CPS has no information on actual experience beyond that accumulated in the year prior to the survey. But the similarity between the PSID and CPS with respect to common variables gives one some confidence in analyses using the PSID, since the CPS is a nationally-representative data set.
} 
http://irs.princeton.edu/PDIIMAIN.htm to investigate the importance of measuring actual labor market experience and the feasibility of including a measure of actual experience in crosssectional data sets such as the CPS. We first use the PSID to analyze earnings for various groups, focusing on the impact of actual (compared to potential) experience. The work history variables in the PSID are found to be important in explaining both the gender pay gap as well as the wage determination process for women. In addition, we find that some of what appear to be changes in women's residual wage inequality are in fact explained by changes in their actual work experience. We also use the PSID to compare results using experience measures based on respondents' recall of their work histories (i.e., retroactive experience measures) with measures based on regular, annual interviews in which the past year's activities are catalogued. Since only the former can be used to collect experience data in a cross-sectional survey, it is important to determine whether retrospective experience measures yield significant valid information. And we do indeed find that the retrospective experience data in the PSID match up well with the data based on annual surveys within the PSID panel, suggesting that much can be learned from retrospective work history survey data.

We next analyze data from the PDII survey, which was designed to mimic the CPS in its survey methodology. The survey includes two questions on retrospective work experience, similar to those in the PSID. (See the Appendix for the text of the questions used in each survey). We find that tabulations and analyses using the PDII data are quite similar to those employing the PSID. The PDII data on actual work histories add considerable explanatory power to wage regressions for women, even if they control for potential experience (defined as age minus years of schooling minus 6 , or roughly the number of years that have elapsed since leaving school) and current job tenure. Potential experience may be calculated in virtually all CPS data sets and current job tenure is additionally available in the CPS Tenure Supplement surveys, which are conducted every two years ( see, http://www.bls.gov/news.release/pdf/tenure.pdf). Therefore having data on actual work histories would represent a noticeable improvement over the CPS even when it conducts its Tenure 
Supplement survey. In addition, for a small subset of respondents, the PDII survey asked adults to provide information on a randomly-selected other adult in the household, much as the CPS asks for proxy responses from the person contacted by the Census during its data collection. We find that the responses to questions about total work experience given for proxy adults is similar to that given by respondents of the same gender and marital status about their own work histories.

These findings from the PDII survey suggest that it would indeed be feasible to add two retrospective work experience questions to the CPS annual March supplement and that this addition would yield valuable information for those analyzing labor market outcomes. The inclusion of these retrospective experience questions in the CPS would ensure that we have a representative sample of the adult population with data on actual experience. In addition, since the March CPS has much larger sample sizes than the PSID, it would allow for much more detailed analyses of experience and labor market outcomes than does the PSID.

\section{The PSID Data}

To illustrate the value of measuring actual work experience, we focus on women and the gender wage gap, analyzing extracts from the PSID referring to the 1980, 1990 and 1999 survey years. We thus not only study the role of experience at a point in time, but we also provide analyses of changing levels of experience, which were indeed dramatic for women, especially in the 1980s (O’Neill and Polachek 1993; Blau and Kahn 1997 and 2006). Whenever people join the PSID panel for the first time as a head or wife, they are asked how many years they worked since they were 18 years old, and, of these years, how many involved full-time work. In addition, in 1976 and 1985, the PSID asked all heads and wives these two questions, regardless

of when they joined the panel. The answers to these questions form the base we use to calculate actual total experience, full-time experience, and part-time experience (defined as total experience minus full-time experience). Once we have these initial values for the experience 
variables, we fill in the period between the date these questions were asked and the focal survey year (e.g., 1980, 1990 or 1999) by using the longitudinal work history data collected for all heads and wives in the years after they join the panel or in the years after 1976 or 1985, whichever came last.

For example, suppose one joined the panel in 1987 and we want to compute total, fulltime and part-time experience as of the 1990 survey. This information was collected as of 1987. We then add 1 to total labor market experience for each year between 1987 and 1990 in which the person worked positive hours and 1 for full-time experience for each year the person worked at least 1500 hours. Part-time experience is increased by 1 for each year in which annual hours are positive but less than 1500. The collection of retrospective experience data in 1976 and 1985, in conjunction with the annual questions about the previous year's work activity, allow us to compare (i) the retrospective 1985 value of experience with (ii) one constructed over the 1976-1985 period based on the 1976 value of experience and the annual increments the respondent reports during the interim.

Using these procedures enables us to obtain the experience history of all respondents for all years of the survey with one exception: the PSID began skipping alternate years with the 1999 survey, meaning that there was no 1998 survey. We therefore have no information on annual work hours between 1997 and 1998. To fill in this missing year of experience, we use the 1999 sample to estimate, separately by gender, logit models for having positive work hours and for working at least 1500 hours in the previous year and in the year preceding the 1997 survey $^{8}$ The explanatory variables include race, a set of education variables including years of schooling and dummies for college degree (no advanced degree) and advanced degree, full-time and parttime experience as of 1997 and their squares, a marital status indicator and the number of children living with the respondent. To estimate total, part-time and full-time experience for the

\footnotetext{
8 Those who joined the panel in 1999 are excluded from this analysis since we do not observe them in the 1997 survey. Note that we already have complete work experience data for such individuals since they were asked the retrospective experience questions when they joined the panel.
} 
missing year (i.e., the year between 1997 and 1999), we average the two predicted values for these variables from the 1999 and the 1997 logits.

\section{Using the PSID to Study the Importance of Actual Experience in Understanding Earnings}

We use the 1980, 1990 and 1999 waves of the PSID to compute wages for 1979, 1989 and 1998. We restrict our analysis of wages to respondents who were, as of the survey date, employed wage and salary workers age 18-65. To maximize sample size, we use both the PSID's random sample and its poverty oversample populations and, in all analyses, employ the sampling weights supplied in the PSID files. The wage measure is average real hourly earnings during the previous calendar year expressed in 1983 dollars using the Personal Consumption Expenditures deflator from the National Product Accounts. We exclude individuals earning less than \$1 or more than \$250 per hour in 1983 dollars.

Table 1 shows mean values for the key variables in our analysis separately by gender for 1980, 1990 and 1999. For men, potential experience, actual experience, and full-time experience are all very similar, suggesting that using potential experience in wage analyses for men is likely to yield fairly good estimates of the return to actual work experience. ${ }^{9}$ This does not, however, rule out the possibility that an actual experience measure could be more important for some subgroups of men. Women have considerably lower levels of actual and full-time experience and slightly more part-time experience than men. The gender gap in experience closes in both decades, with a larger fall in the 1980s: the gender gap in total experience was 5.6 years in 1980, 3.5, years in 1990, and 2.3 years in 1999. For women, potential experience overstates actual experience by fully 5.5 years in 1980, although due to women’s increasing commitment to the

\footnotetext{
${ }^{9}$ Note that for men, actual experience is slightly higher than potential experience in 1990 and 1999 . This is the case because potential experience is defined as (age-years of schooling-6), while the measure of actual experience starts at age 18. As expected, however, (age minus 18) always has a higher mean than actual experience.
} 
labor market, the overstatement falls to 2.5 years by 1999. Not surprisingly, potential experience does an even worse job of proxying for women's full-time experience, overstating it by 8.7 years in $1980,7.1$ years in 1990 and. 6.4 years in $1999 .^{10}$

Tables 2 and 3 show alternative specifications of the experience variable in human capital wage regressions. ${ }^{11}$ In each case for women, the returns to actual or full-time experience are considerably larger than the returns to potential experience, likely reflecting the impact of labor force interruptions. ${ }^{12}$ In contrast, for men, the potential experience effects are nearly the same size as the effects of actual experience, presumably reflecting the smaller incidence of work interruptions for men. Figure 1 shows the implications of these wage functions for women's experience-earnings profiles. In each year, using actual or full-time experience yields a considerably steeper profile than using potential experience. For example, in 1999, female wages are predicted to rise by $0.14-0.15$ log points more after 20 years of actual or full-time experience than after 20 years of potential experience. Given that the raw gender pay gap was $0.275 \log$ points in 1999 (Table 1), this is a substantial difference. The profiles indicate that failure to collect data on actual work histories causes one to severely underestimate women’s accumulation of on the job human capital. In contrast, not surprisingly, men receive a similar return to 20 years of potential, actual or full-time experience. An additional finding worth noting is that the gender gap in the return to actual or full-time experience was lower in 1999 than in

\footnotetext{
10 The PSID does contain information that allows one to compute the time since leaving school, a perhaps more accurate indicator of potential experience, although with the prevalence of employment among college students, this alternative measure may be problematic as well. We use the more standard measure of potential experience here since our purpose is to investigate the value of adding simple questions about actual experience to nationallyrepresentative data sources such as the CPS, which do not generally collect information on the date of leaving school.

${ }^{11}$ We include dummy variables for college and advanced degrees in addition to the linear years of school variable to allow for nonlinearities in the return to education. This may be particularly important in light of the marked increase in the share of the college educated who were women. For example, while in 1980 the number of women who were enrolled in four year institutions was roughly the same as the number of men, by 2003, there were 1.30 women for each man at such colleges and universities (Goldin, Katz and Kuziemko 2006, p. 134). Results were similar when we excluded the college and advanced degree dummies.

12 For simplicity we refer to both (i) labor force withdrawals and (ii) gaps between completing school and labor force entry as "interruptions.” Our data do not in any case permit us to distinguish between the two.
} 
1980. This change likely reflects an increase in the relative quality of women's work experience, as women were investing in careers to an increasing extent (see also O’Neill and Polachek 1993).

We also experimented with alternative specifications in assessing the importance of actual experience measures in explaining the gender pay gap. Specifically, several analyses have emphasized the possible deterioration of skills when workers leave employment, including Mincer and Polachek (1974), Spivey (2005), Gorlich and de Grip (2009), and Bertrand, Goldin and Katz (2010). Moreover, the impact of work interruptions may be nonlinear, as short career interruptions may have less serious effects than long interruptions. On the other hand, in some labor markets, even short interruptions may greatly reduce one's wage growth by eliminating the chance to move up fast track career ladders. ${ }^{13}$ Thus we estimated models including dummy variables for time out of work (break time) of 1-2 years, 2-3 years and 3+ years, in addition to the actual experience variables. While we expect time out to lower wages, break time is also positively correlated with age, controlling for education and actual experience. Therefore, the effect of break time will be the net result of the possibly opposing forces of skill deterioriation and aging. The results of these analyses are shown in Appendix Tables A1. Comparison of Table 3 and Table A1 shows that the coefficients for actual labor market experience are similar whether or not we control for break time. The break time coefficients themselves were generally negative (although not always significant), suggesting the deterioration of skills during periods out of the labor force. We should point out that the timing of labor force withdrawals can also affect wages, although the PSID does not allow one to determine when the withdrawals took place. $^{14}$

Table 4 shows the consequences of using the various measures of experience for the unexplained overall gender pay gap and also race pay gaps separately by gender. The figures are

\footnotetext{
13 For example, in a study of MBA graduates from a leading business school, Bertrand, Goldin and Katz (2010) find that, in this high level labor market, even career interruptions as short as six months have very large negative consequences for wage growth.

${ }^{14}$ Spivey (2005), using National Longitudinal Survey of Youth data, finds little additional effect of the timing of labor market experience on the gender pay gap, however.
} 
obtained by taking average female residuals from male wage equations (Panel A) or average nonwhite residuals from white wage regressions run separately for men (Panel B) or women (Panel C).

Looking first at Panel A, we see that, in each year, the unexplained gender pay gap is smaller using actual than potential experience and smaller still using the disaggregated part-time and full-time experience variables. Additionally controlling for break time moderately reduces the unexplained gender pay gap in 1990; but does not affect the results for the other two years. ${ }^{15}$ The difference between the results for actual and potential experience can be substantial. For example, in 1980, replacing potential with actual experience lowers the unexplained pay gap from .466 to .389 , for a reduction of .077 log points. Replacing actual experience with the fulltime and part-time experience variables results in an additional reduction to .341, or a fall of .048 $\log$ points. By 1999, as would be expected, the effects in each case were smaller, but, interestingly, we add as much information by disaggregating actual experience into its full-time and part-time components as we do by replacing potential with actual experience. In each case the unexplained gap falls by .028 log points. Thus, for estimating ceteris paribus gender pay gaps, it is clearly better to use actual rather than potential experience, but it is also advantageous to be able to decompose work histories into part-time or full-time experience. The results also show that, in all three specifications, the ceteris paribus gap declined over the period as a whole, with the decline centered on the 1980s. ${ }^{16}$ However, Table 4 indicates that the potential experience specification considerably overstates this decline because it reflects the impact of the decreasing difference between actual and potential experience, as well as the decrease controlling for actual total or full-time experience.

Panel B of Table 4 shows that unexplained race pay gap for men declines by about one percentage point when we replace potential experience with actual full-time and part-time

\footnotetext{
${ }^{15}$ Using the female equation and the male means for specifications including break time (results not shown) yields a larger unexplained gender gap for 1980 and 1990, but a smaller unexplained gender gap for 1999 (compared to the estimates shown for this specification in Table 4).

${ }^{16}$ These results are consistent with those reported by Blau and Kahn (2006).
} 
experience, reflecting nonwhite males’ higher joblessness. Moreover, perhaps reflecting the worsening economy facing less skilled workers, the unexplained race pay gap rises in absolute value, particularly in the 1980s when the bottom of the wage distribution fared the worst (Autor, Katz and Kearney (2008). Panel C shows the race gap for women. In contrast to men, the unexplained gap for nonwhite women actually becomes more negative (or less positive for 1999) when we replace potential experience with actual full time and part time experience. This pattern occurs because of nonwhite women's higher levels of actual labor market experience relative to that of white women. Thus, failure to obtain data on actual experience, then, leads one to make an upward biased estimate of nonwhite women's wages relative to those of comparably-qualified white women. Table 4 also indicates that the position of nonwhite women deteriorated in the 1980s, as it did for nonwhite men, but, in contrast to nonwhite men, it improved in the 1990s.

Finally, Appendix Table A2 compares the overall performance of regressions of women’s wages on potential experience, aggregated total experience, or disaggregated full-time and parttime work experience based on the PSID data. In addition, the Table shows results for residual wage inequality for each specification. The purpose of the table is to compare the performance of models that use the type of data available in the CPS, where data on experience are not available, with those that include the experience variables. Table A2 shows that both the unadjusted and adjusted $\mathrm{R}^{2}$ rises noticeably in each year when we replace potential experience with the work experience variables. For example, in 1999, the $\mathrm{R}^{2}$ adjusted for degrees of freedom rises from 0.211 to 0.247 , and then again to 0.267 as we move from the potential experience specification to the total experience and then the full-time and part-time experience specifications-with a similar progression for the unadjusted $\mathrm{R}^{2}$. The rising unadjusted $\mathrm{R}^{2}$ of course implies falling residual inequality as we replace potential experience with actual work history data. Moreover, the last column shows the changes in both $\mathrm{R}^{2}$ measures and in the residual variance over the 1980-1999 period. In the potential experience specification, which would be the only one available in the March CPS, residual inequality rises by 0.068 log points 
between 1980 and 1999; however, in the full-time and part-time work experience specification, it rises by 0.056 log points, or about $18 \%$ less. While this is not a dramatic difference, it does suggest that the previous literature may have overestimated the level and increase in women's residual inequality and therefore the extent to which rising prices of unmeasured skills have contributed to rising wage inequality among women, on the assumption that changes in residual inequality reflect changing prices of unmeasured skills (Juhn, Murphy and Pierce 1993). ${ }^{17}$

The last specification in Table A2 shows a model with both potential experience and disaggregated full-time and part-time experience included. This is comparable to the break-time specification discussed above in that it implicitly controls for workforce interruptions. Further it provides additional information on whether including controls for the components of actual experience improves the fit of the model compared to the potential experience specification. As would be expected, the results in Table A2 indicate that both the unadjusted and adjusted $\mathrm{R}^{2}$ are noticeably higher in each year, and residual inequality is lower, when the actual experience variables are added to a model which includes potential experience. Moreover, the $\mathrm{R}^{2}$ and residual inequality are very similar to the model just using the disaggregated full-time and parttime experience measures, suggesting that controlling for time out of the labor force does not contribute much to the fit of the model. (The results for residual inequality were virtually identical when we replaced the potential experience variables with the dummy variables for break time.)

\section{Long vs. Short Recall in the PSID’s Retrospective Measures of Work Experience}

\footnotetext{
17 We reference Juhn, Murphy and Pierce (1993) in the text above because they suggest this interpretation of the trends in the residual, although their sample is restricted to males. We also note that, of course, rising returns to experience could have contributed to women's rising experience levels. Nonetheless, it is still of interest to ask what happened to wage inequality among women who have the same human capital levels (including schooling and actual experience), a question that can only be answered with work history data.
} 
As mentioned earlier, the PSID collected retrospective experience information for all heads and wives as of 1976 and 1985. For those who were in the panel continuously between these years, it is possible to compute 1985 experience in two ways: (i) using the 1985 survey response to the experience questions; and (ii) using the 1976 survey response augmented by the annual responses to the work activity questions between 1976 and 1985. Method (ii) should in principle yield the more accurate experience measure, since it is based in part on annual reports requiring only one year's recall. These annual reports are used to compute the increments to the 1976 experience measure (which of course must be based on one's recall of prior experience as of 1976 of each year since age 18). In contrast, method (i) merely uses answers to the 1985 survey, which requires that one recall work activity in each year since age 18, as of 1985 . One might further speculate that the 1976 report is more accurate than the 1985 report because a shorter time had elapsed since age 18 in 1976 and one’s memory may deteriorate with age and/or the pattern that one is trying to recall becomes longer and more complex with age.

Table 5 shows mean values for these alternative measures of labor market experience among women who were employed wage and salary workers in 1985 and who were in the panel continuously from 1976 to 1985 . The mean constructed 1985 experience level (17.97 years) is only slightly different from the mean 1985 experience tabulated from the 1985 retrospective survey question (18.41). There is a slightly larger gap for 1985 full-time experience (12.95 years constructed vs. 14.78 years from the retrospective survey question), which may be due to differences between our interpretation and the way in which survey respondents have interpreted the notion of full-time experience. ${ }^{18}$ There is, moreover, an average difference between survey and constructed 1985 experience of 2.81 years in absolute value, which is slightly larger (3.63) for full-time experience. ${ }^{19}$

\footnotetext{
${ }^{18}$ Recall that in the survey, respondents are asked only whether they worked full time (for most or all of the year), whereas we have used a 1500 annual work hour cutoff. However, results were similar when we used a 1200 hour cutoff instead.

${ }^{19}$ We focus on women because of their greater likelihood of interrupted careers. Not surprisingly, there was a closer match between constructed and retrospective experience measures for men, with differences in the absolute
} 
Table 6 explores the determinants of the absolute value of the difference between the constructed and survey values for 1985 work experience. It shows that, generally, white, younger and more educated ${ }^{20}$ respondents have smaller differences between the two measures. If younger individuals have better memories (and/or a shorter, less complex time period to recall) and whites have higher quality schooling than nonwhites, then the regression results in Table 6 support the idea that the difference between the two experience measures represents greater recall errors in the 1985 survey compared to the annual reports of work activity between 1976 and 1985. The Table suggests that we do gain something by using annual reports of experience during the previous year compared to one-time retrospective questions.

Tables 7 and 8 provide some indirect evidence on the size of the gain in information from utilizing the annual reports of work activity between 1976 and 1985 relative to the retrospective 1985 report of experience. If the constructed experience variable is indeed more accurate than the survey variable, then we should expect to see a larger effect of the former on wages. Table 7 indeed shows a slightly higher main effect of constructed (0.049) vs. survey (0.044) experience, with identical quadratic terms (-0.0008). And using the constructed measures as instruments for the survey measures boosts the main effect to 0.054 with a slight rise in absolute value for the quadratic term, reflecting the common signal in the two measures of experience. But overall, Table 7 suggests that we do not gain very much by using the annual reports between 1976 and 1985 versus the 1985 retrospective data. In either case, the main effect of estimated actual experience is well above the main effect of potential experience, which is only 0.002 and is not even statistically significant (the quadratic term for potential experience is very small and also insignificant) ${ }^{21}$. Finally, Table 8 shows similar results for full-time experience. We obtain a

\footnotetext{
value of the two measures averaging 1.36 years for experience and 2.26 years for full time experience, considerably less than the figures cited above for women.

${ }^{20}$ In the first and third specifications (omitting controls for college and advanced degree), the coefficient on years of schooling is negative and significant. The addition of controls for college and advanced degree in the second and fourth specifications does not appear to provide any additional information.

${ }^{21}$ Recall that the results in Tables 7 and 8 are based on a subsample of respondents who were in the panel continuously between 1976 and 1985 and thus may differ from results presented earlier for the full sample.
} 
small increase in its coefficient when we use the constructed, as opposed to the survey, variables and a further slight increase when we use instrumental variables. ${ }^{22}$

The overall message from the analyses in Tables 7 and 8 is that collecting retrospective experience data is likely to be adequate for many purposes, although the PSID does demonstrate that disaggregating this into full-time and part-time components would be useful. Thus, having information on actual experience, whether it is collected retrospectively or constructed from annual reports of work activity, represents an important improvement over data that only allow us to compute potential experience. Moreover, the small gains in apparent accuracy in using the annual reports vs. the retrospective information suggest that cross-sectional data sets like the CPS could indeed usefully add retrospective questions about work histories. This conclusion is based of course on the nine year period 1976-85. It is possible that larger differences in results between models based on retrospective versus concurrent measures of experience would have emerged if annual interviews had begun when each respondent was 18 years old.

\section{Analyzing Experience Data in a Telephone Survey: Results from the PDII Survey}

As part of the Princeton Data Improvement Initiative, in 2008, Westat surveyed 2513 adults by telephone and collected a variety of labor market and demographic information from the respondents. We used these data to study the feasibility of adding two retrospective experience questions to a cross-sectional survey like the March CPS. Part B of the Appendix shows the experience questions asked in the survey; they are quite similar to the retrospective experience questions in the PSID (shown in Part A of the Appendix). ${ }^{23}$ Specifically, respondents were asked to state the number of years since age 18 in which they did any work for pay

\footnotetext{
22 The effect of part-time experience does increase markedly using the instrumental variables estimation, however.

${ }^{23}$ We made some small changes in the PSID wording of these questions either for consistency with other CPS questions or in the interest of clarity based on the results of pre-tests of the questions by Westat.
} 
(counting all years in which they worked either all or part of the year) and, of those years, how many involved full-time work for at least half of the year.

We first consider the results of a consistency check of these questions. If one answered the experience questions correctly, actual work experience or full-time work experience can be no greater than age-16 (age minus 16) years. For example, suppose one was born in November 1980, and had worked continuously since turning 18 in November 1998. Since the survey took place before November 2008, this respondent would be 27 years old as of the survey date and would have worked in a total of 11 years. For 124 respondents (about 5\% of the sample), measured experience was greater than (age-16), although in 79 cases (64\% of the 124), the excess was three years or less. Westat resurveyed 38 of these individuals, with the heaviest coverage for those with an excess of reported experience over (age-16) of at least four years, and obtained corrected answers to the experience question. In most cases, the respondent forgot that only years since age 18 should be counted. After the resurvey, in 91 cases of 2513 (3.6\% of the sample), the experience data were inconsistent with the age 18 directive (principally individuals who were not resurveyed), and about 2/3 of those had excess reported experience of one or two years. As shown below, the manner in which these inconsistencies are treated has virtually no effect on one's conclusions from analyzing the data. This suggests that asking respondents to compute their experience levels in a phone survey is indeed useful and does not yield serious enough errors in consistency to bias the results.

Table 9 provides some descriptive statistics for the PDII sample. ${ }^{24}$ We have restricted the age range to 18-65 in all cases. Table 9 shows data for all adults and also the corresponding data for wage earners. First, note that we have provided three definitions of total experience, fulltime experience, and part-time experience: (i) the unedited survey responses; (ii) the survey responses after Westat re-surveyed 38 of the respondents with inconsistent data; (iii) the post-resurvey responses edited so that experience is truncated so as never to be greater than age-18 (the

\footnotetext{
${ }^{24}$ Westat supplied a set of sampling weights which we used in all analyses.
} 
Michigan Survey Research Center performs a similar edit of reported experience greater than age-18 in the PSID). In each case, the mean and standard deviation of the experience variables are hardly affected by the different definitions. For example, among women in the full sample (Table 9, Panel B, first column), total experience under these definitions averages between 20.5 and 20.9 years, a very tight range. While this agreement across these different measures does not eliminate the possibility of recall errors, it is reassuring.

If the PDII data are indeed representative of the US population, then the experience gap between men and women has decreased between the PSID’s 1999 data (Table 1) and 2008, when Westat conducted its survey, particularly for full-time experience. For example, among wage earners (Table 9, third column), the gaps are 2.8-2.9 years more full-time and 1.4 years less parttime experience for men than women, for a total experience gap of 1.4-1.5 years favoring men. These are smaller in magnitude than the gaps shown for wage earners in the PSID as of 1999: 4.6 years more full-time and 2.3 years less part-time experience for men, adding up to a 2.3 year male advantage in total experience. For men, the average level of total experience (21.2 years) in the 1999 PSID is very similar to the level for wage earners in the PDII data as shown in Table 9 (21.7-22.0 years), whereas women’s experience is slightly higher in the PDII data (20.3-20.6 years as shown in Table 9 vs. 18.9 years in the PSID data as shown in Table 1). Table 9 also shows that female wage earners had higher schooling levels than males by about 0.30 years, a slight widening from 1999's female advantage of 0.16 years. Thus, the PDII data suggest that women continued to improve their human capital relative to men between 1999 and 2008; a trend that began in the 1980s (see O’Neill and Polachek 1993; and Blau and Kahn 1997 and 2006).

We also computed mean values for married adults and married adult wage earners (data available upon request). In both cases, the gender gap in experience is larger than for the adult population as a whole or adult wage earners, as would be expected under a traditional division of labor in the family. For example, among married wage earners, men have 4.8 years more fulltime and 1.9-2.0 years less part-time experience than women compared to a full-time gap of 2.9 
years favoring men and a part-time gap of 1.4 years favoring women among adult wage earners. The larger gender experience gaps (and, as shown below, gender wage gaps) for married people vs. all adults provide further evidence for the credibility of the PDII survey, and by implication, a similarly designed experience module in the CPS.

Table 10 shows the results of computing the unexplained gender pay gap under various specifications of the (male) wage equation (regression results are shown in Appendix Table A3). The dependent variable is the log of average hourly earnings, and its computation takes into account the time period for which one is paid (i.e., hourly, weekly, etc.). ${ }^{25}$. The raw pay gap for all women is 0.29 log points on average, similar to its level in the 1999 PSID (0.28). Using a wage equation with controls for education, potential experience (and its square) and race, the unexplained gender pay gap rises to $0.32 \log$ points. ${ }^{26}$ This increase occurs because women have roughly the same number of years of potential experience as men but, as noted, about 0.3 years more schooling. Replacing potential experience with total actual experience lowers the unexplained gender pay gap to $0.303-0.304$ log points, or a 0.015-0.016 log point reduction. Further disaggregating the experience variable into full-time and part-time components reduces the unexplained gap by another 0.014-0.017 log points. These changes in the unexplained gap are qualitatively similar, although smaller in magnitude, to those for the 1999 PSID. This decrease in magnitude is likely lower gender gap in experience in the 2008 PDII survey than in the 1999 PSID. This may be due an actual decline in the gender experience gap over this period, but could also be due, in whole or part, to unknown differences between the two surveys. The PDII experience data are thus able to explain about 3 percentage points of the unexplained pay gap, or about $10 \%$ of it. The results for married workers (the second column of Table 10) are similar, although the raw gap and the unexplained gaps are 8-10 percentage points higher than

\footnotetext{
${ }^{25}$ We are indebted to Alan Krueger for his careful construction of the hourly earnings variable from the raw earnings, pay period and work hours responses in the PDII survey.

26 As may be seen in Table A3, the wage equations control only for years of schooling, while our analyses using the PSID added dummies for college degree and advanced degree to the specification. When we included these additional variables in analyzing the PDII data, the results for the gender pay gap and the impact of various experience measures on wages were very similar.
} 
for all women, as might be expected. As in the case of the PSID-based analysis, the results are similar when we control for break time, modestly reducing the unexplained gap for all workers and very slightly increasing it for married workers (see the last row of the table). ${ }^{27}$

Looking more closely at the regression results in Table A3, we see that the estimated returns to education are about $8-10 \%$, a range that is consistent with earlier research on the returns to schooling in the United States (see, for example, Card 1999). For men, the returns to actual experience are slightly higher than the returns to potential experience, as one might expect. However, among women, the returns appear to be about the same. For example, after 20 years, the potential experience equation yields a wage increase of 0.56 log points (relative to new workers), while the aggregated actual experience equations yield an increase of 0.50 log points. The effect of 20 years of full-time experience is slightly smaller, at 0.44 log points.

One might have expected a higher return to actual than to potential experience for women, and the fact that we do not observe this may indicate the presence of measurement errors in the PDII experience data. ${ }^{28}$ We studied the issue of measurement error in the experience variable by instrumenting for actual experience and its square with potential experience and its square. $^{29}$ Because there are only two instruments, we were not able to disaggregate the actual experience variable into its full- and part-time components. We indeed found a steeper profile using instrumental variables (IV) than ordinary least squares (OLS): the IV results imply that after 20 years of actual experience, women's wages rise 0.79 log points relative to new workers, in contrast to the 0.49 level for the OLS estimates. For men, the differences between the profiles using OLS and IV are much smaller. In particular, after 20 years of actual experience, men’s wages rise by 0.57 in the OLS model using actual experience, and by 0.60 in the IV actual

\footnotetext{
27 As was the case with the PSID, Table A3 shows that the break time variables generally lowered wages.

${ }^{28}$ Actually, Mincer and Polachek (1974) also find a larger effect for potential experience than for actual experience before they disaggregated actual experience into segments relating to childbirth. Unfortunately, the PSID data don't allow such a detailed analysis of work history, although, as the findings here suggest, having information on actual experience is an important improvement over the potential experience measure.

${ }_{29}$ Of course, there may be other reasons to instrument experience, since it is likely to be affected by labor market outcomes.
} 
experience model. These IV analyses are consistent with the idea that measurement errors may be more severe for women than men and that, once corrected, women actually have steeper experience-wage profiles than men. ${ }^{30}$

These IV models are only suggestive, however, since it is possible that both potential and actual experience belong in wage equations to capture the effect of time out of the labor force. Further, as note earlier, the inclusion of the actual experience variables in a model that controls for potential experience sheds light on whether this additional information improves the fit of the model. In Table A4 we present goodness of fit and residual inequality results for this and a number of other alternative specifications of the female wage equation estimated on the PDII data, again (as with the PSID results presented earlier) with the goal of evaluating the performance of models including actual experience relative to those with potential experience only. The experience measures in Table A4 are based on post-resurvey data in which experience is constrained to start at age 18. The first three specifications in Table A4 show very similar $\mathrm{R}^{2} \mathrm{~s}$ and residual inequality for the potential experience, aggregated total actual experience, and disaggregated full-time and part-time experience specifications. However, when we include both the potential experience and disaggregated actual experience variables, we obtain a somewhat higher $\mathrm{R}^{2}$ and lower residual inequality. Moreover, the actual experience variables are highly significant as a group in this specification. In particular, even controlling for potential experience, a woman with 20 years of full-time experience outearns one with no full-time experience by 0.32 log points, all else equal. In other words, the actual experience variable

\footnotetext{
${ }^{30}$ The endogeneity of experience could also help explain why the IV estimates are different from the OLS estimates. However we would expect the endogeneity bias to be positive- the unmeasured factors that lead to higher wage offers are likely to be positively correlated with commitment to the labor market and thus accumulated work experience. In contrast, measurement error produces a downward bias in the OLS estimates. The fact that we observe larger IV than OLS effects of experience is thus consistent with the measurement error interpretation. In the PSID data, instrumented experience models produce a slightly less steep profile than OLS experience models, suggesting that in 1999, the endogeneity biases dominated any measurement error biases. Perhaps the endogeneity biases are less severe today, to the extent that women's labor supply is less sensitive to earnings opportunities than it was in the past (Blau and Kahn 2007).
} 
coefficients imply considerable variability in wages among women with the same potential experience. $^{31}$

The PDII survey also asked workers how long they had been with their employer, a question that the CPS asks every two years in its Tenure Supplement (see above). The PDII data thus allow us to determine whether the CPS tenure data, in conjunction with potential experience, are sufficient to summarize women's work histories. If so, then the Tenure Supplement would be sufficient for analyzing the gender pay gap and women’s wage determination in general. The results in Table A4 indicate that adding the disaggregated actual experience variables to a model that already includes tenure and potential experience leads to a higher $\mathrm{R}^{2}$ (raising it from 0.323 to 0.351 ) and a slightly lower residual variance. (The regressions are shown in Table A5.) More importantly, we reject the hypothesis at the 0.0000 to 0.0002 significance level that the actual experience variables add no explanatory power. And, controlling for tenure and potential experience, a woman with 20 years of full-time experience outearns one with zero years of full-time experience by 0.33 log points. Therefore adding work history variables even to the CPS Tenure Supplements would noticeably improve our understanding of women's wage determination. ${ }^{32}$

Finally, as mentioned, the CPS conducts a telephone survey, with the responding adult providing data for the related adults in the household. To test the feasibility of such proxy reporting for the experience questions, we asked a random subset of the respondents in the Westat survey to provide data on a randomly chosen other adult in their household. This allows us to study the effects of proxy reporting on the quality of the experience data collected. To gauge the quality of these data, we compared the proxy responses for spouses with the sample averages of self-reports for married respondents. Table 11 shows the results of these comparisons. Although the number of spouses for whom proxy responses were obtained is

\footnotetext{
31 The actual experience wage profiles were not affected when we included a series of dummy variables for break time defined earlier.

32 Again, replacing the potential experience variables with the break time variables led to very similar results.
} 
relatively small (48 husbands and 51 wives), the data match up well with that of married respondents of the same sex. This correspondence gives us some confidence that the CPS could profitably collect proxy data on work experience from its March Supplement respondents.

\section{Conclusions}

In this paper, we used PSID data and data from a 2008 telephone survey of adults conducted by Westat for the PDII to explore the importance and feasibility of adding retrospective questions about actual work experience to a cross-sectional data set like the March CPS annual supplement. We demonstrated that having such actual experience data is important for analyzing the gender pay gap, since women continue to have less labor market experience than men, and on-the-job training and learning have been shown to be important components of post-school human capital accumulation. We find that having information on actual full-time and part-time work experience can explain up to 35\% of the unexplained gender pay gap in the 1999 (using the PSID) and 18-19\% of the unexplained pay gap in the 2008 PDII data. Moreover, inclusion of information on actual experience is helpful in understanding wage determination of women as well as for analyzing female wage inequality. Experience profiles for women are generally found to be much steeper when we use actual full-time and part-time experience rather than potential experience. Failure to include such data causes us to severely underestimate women's on the job human capital accumulation. Moreover, using potential rather than actual experience causes us to overstate the increase in women's residual wage inequality from 1980 to 1999 by about $20 \%$.

In terms of the retrospective experience data itself, we show that while annual recall appears to be slightly more accurate than long recall, the difference in the quality of experience measures based on each is small. This result has important implications for annual independent cross-section data such as the CPS, since the experience questions could be asked at most only twice of each respondent (once in their first four months in the CPS and once in the second 
fourth month period). ${ }^{33}$ Finally, we showed that a telephone survey of respondents produces credible data on work experience, both for actual respondents and for proxy respondents in the household. Again, the CPS operates in a similar way, suggesting that the CPS could also collect proxy experience data that would be useful. We thus conclude that adding retrospective experience questions to the March CPS would help us understand not only the gender pay gap and female wage determination but likely also gaps along other dimensions such as race, education, or nativity status. Such information would likely also be helpful in efforts to understand the long-term effects of the Recession of December 2007, which likely produced significant work force interruptions for broad segments of the population. In addition, with more accurate data on actual work experience, we can better understand the wage determination process through wage regressions that correspond to original notions of human capital.

\footnotetext{
33 The short panel of the CPS could be used to address possible measurement errors in recall by using, say, the first estimate of experience as an instrument for the second.
} 


\section{Appendix}

\section{A. Experience Questions from the Panel Study of Income Dynamics ${ }^{34}$}

\section{Retropective Experience Questions}

The following questions were asked of heads (as illustrated below), both those who were currently employed and those who were not currently employed; they were also asked of wives, both currently employed and currently not employed.

1. How many years altogether have you (HEAD) worked for money since you were 18 ?

The values for this variable represent in whole years the actual amount of time the Head had worked since the age of 18 until the time of the interview.

2. How many of these years did you work full-time for most or all of the year?

The values for this variable represent in whole years the actual amount of time the Head had worked full time since the age of 18 until the time of the interview.

3. During the years that you were not working full-time, how much of the time did you work?PERCENT

\section{Annual Experience Questions}

The following questions refer to work during the past year. They refer to heads of families below, but they were also asked for wives. These questions are asked of both the currently employed and those not currently employed.

4. Then, how many weeks did you actually work on your main job in 1984 ?

The values for this variable represent the actual number of weeks (01-52) Head worked on his/her main job.

5. And, on the average, how many hours a week did you work on your main job in 1984 ?

Similar questions are asked about multiple jobs:

6. And, how many weeks did you work on this job in 1984?-ALL EXTRA JOBS EXCEPT FIRST

\footnotetext{
34 The text of these questions is drawn from the 1985 questionnaire.
} 
The values for this variable represent the actual number of weeks (01-52) Head worked on all of his/her extra jobs except the first one.

7. On the average, how many hours a week did you work on this job?-ALL EXTRA JOBS EXCEPT FIRST

The PSID staff combines these weeks and hours answers and computes an annual work hours variable. This is what we use to compute actual ( $>0$ hours) and fulltime ( $>=1500$ hours) experience for each year.

\section{B. Experience Questions from the Westat Survey}

Q36a. Since age 18, in how many years altogether have you worked for pay or profit? Please count all years in which you worked either all or part of the year.

(IF NECESSARY: Your best estimate is fine)

YEARS

ZERO YEARS / NEVER WORKED ............0 (Q37)

REF …...................................................97 (Q37)

DK......................................................98 (Q37)

Q36b. You told me that you have worked in a total of [fill] years since age 18. In how many of these years did you work full-time for more than half the year?

(IF NECESSARY: Your best estimate is fine)

YEARS

REF …................................................. 97

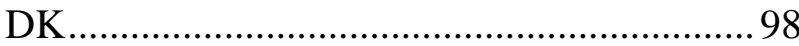




\section{References}

Autor, David H., Lawrence F. Katz, and Melissa S. Kearney. 2008. Trends in U.S. wage inequality: Revising the revisionists. Review of Economics and Statistics 90 (May): 300323.

Becker, Gary S. 1962. Investment in human capital: A theoretical analysis. Journal of Political Economy 70 (October, Part 2): 9-49.

Bertrand, Marianne, Claudia Goldin, and Lawrence F. Katz. 2010. Dynamics of the gender gap for young professionals in the corporate and financial sectors. American Economic Journal: Applied Economics 2 (July): 228-255.

Blau, Francine D., and Lawrence M. Kahn. 1997. Swimming upstream: Trends in the gender wage differential in the 1980s. Journal of Labor Economics 15 (January Part 1): 1-42.

Slowing Convergence. Industrial \& Labor Relations Review, Vol. 60, No. 1 (October), pp. 45-66.

married women: 1980-2000. Journal of Labor Economics 25 (July): 393-438.

Blau, Francine D., Lawrence M. Kahn, and Kerry L. Papps. 2011. Gender, source country characteristics and labor market assimilation among immigrants: 1980-2000, The Review of Economics and Statistics 93 (February): 43-58.

Card, David. 1999. The causal effect of education on earnings. In Handbook of Labor Economics, Volume 3A, ed. Orley Ashenfelter and David Card. Amsterdam: NorthHolland, pp. 1801-1863.

Center on Budget and Priorities, Chart Book: The Legacy of the Great Recession, see http://www.cbpp.org/cms/index.cfm?fa=view\&id=3252 (accessed on July 14, 2011).

Goldin, Claudia, Lawrence F. Katz, and Ilyana Kuziemko. 2006. The homecoming of American college women: The reversal of the college gender gap. Journal of Economic Perspectives 20 (Fall): 133-156.

Görlich, Dennis, and Andries de Grip. 2009. Human capital depreciation during hometime. Oxford Economic Papers 61 (April, Suppl. 1): i98-i121.

Juhn, Chinhui, Murphy, Kevin M., and Pierce, Brooks. 1993. Wage inequality and the rise in returns to skill. Journal of Political Economy 101 (June): 410-442. 
Katz, Lawrence F., and Kevin M. Murphy. 1992. Changes in relative wages, 1963-87: Supply and demand factors. Quarterly Journal of Economics 107 (February): 35-78.

Lemieux, Thomas. 2006. Increasing residual wage inequality: Composition effects, noisy data, or rising demand for skill? American Economic Review 96 (June): 461-498.

Mincer, Jacob. 1962. On-the-job training: Costs, returns, and some implications. Journal of Political Economy 70 (October, Part 2): 50-79.

Mincer, Jacob, and Solomon Polachek. 1974. Family investments in human capital: Earnings of women. Journal of Political Economy 82 (March/April pt. 2): S76-S108.

O'Neill, June, and Solomon Polachek. 1993. Why the gender gap in wages narrowed in the 1980s. Journal of Labor Economics 11 (January pt. 1): 205-228.

Polachek, Solomon William. 1981. Occupational self-selection: A human capital approach to sex differences in occupational structure. Review of Economics and Statistics 63 (February): 60-69.

Spivey, Christy. 2005. Time off at what price? The effects of career interruptions on earnings. Industrial \& Labor Relations Review 59 (October): 119-140.

Weiss, Yoram, and Reuben Gronau. 1981. Expected interruptions in labour force participation and sex-related differences in earnings growth. Review of Economic Studies 48 (October): 607-619. 
Figure 1: Predicted Log Wages Relative to New Entrants, Women (PSID)

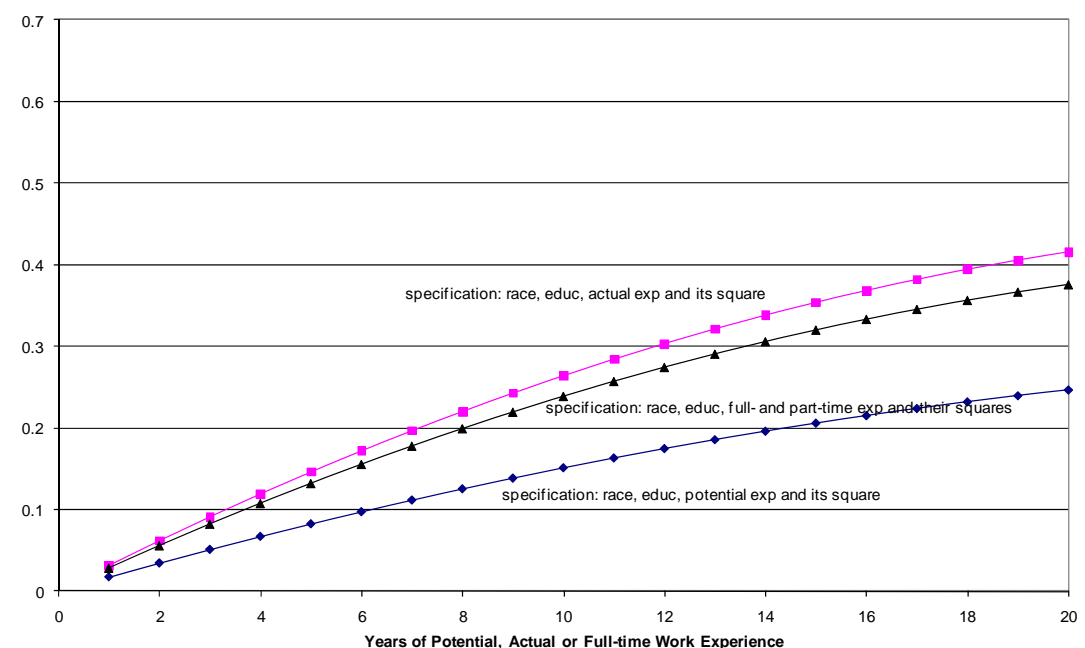

(a) 1980

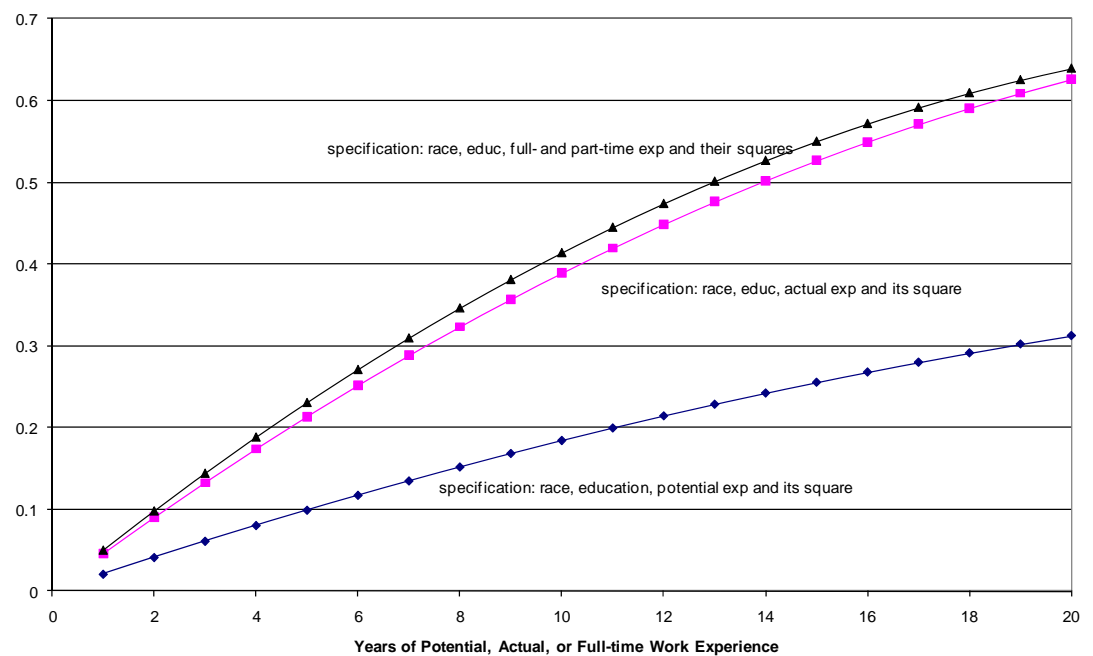

(b) 1990

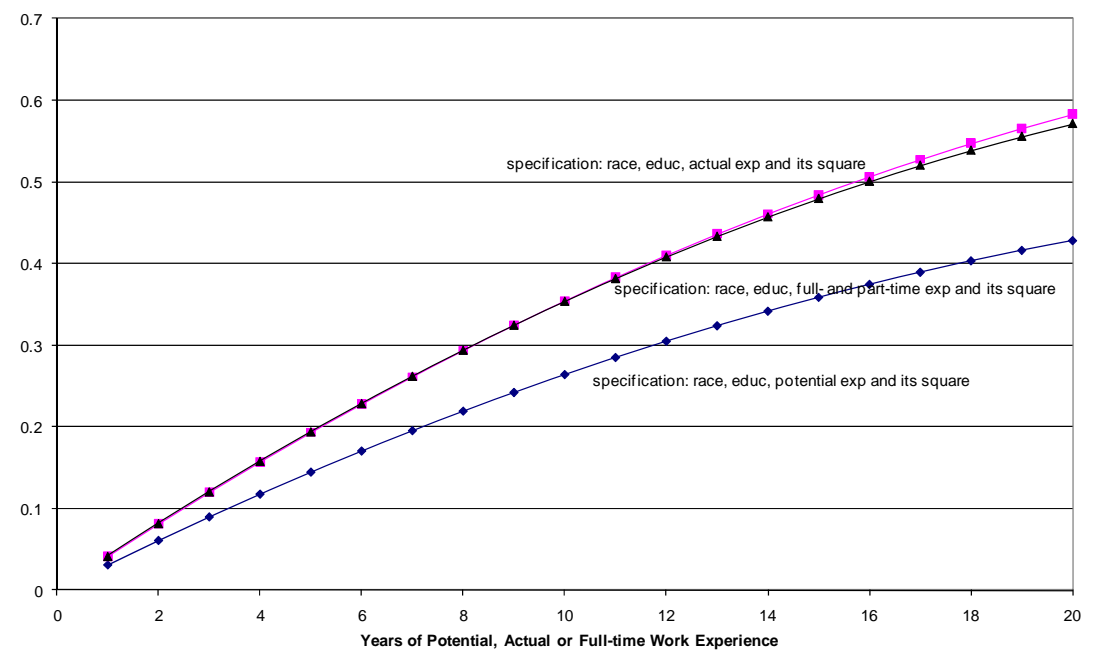

(c) 1999 
Table 1: Selected Mean Values, Nonfarm, Wage and Salary Workers, Age 18-65, PSID 1980, 1990, and 1999

\begin{tabular}{|c|c|c|c|c|c|c|}
\hline & \multicolumn{2}{|c|}{1980} & \multicolumn{2}{|c|}{1990} & \multicolumn{2}{|c|}{1999} \\
\hline & Men & Women & Men & Women & Men & Women \\
\hline Log real hourly earnings & 2.375 & 1.891 & 2.321 & 1.966 & 2.350 & 2.075 \\
\hline White & 0.872 & 0.846 & 0.884 & 0.841 & 0.867 & 0.834 \\
\hline Years of schooling & 12.717 & 12.664 & 13.303 & 13.220 & 13.464 & 13.619 \\
\hline College degree (no advanced degree) & 0.160 & 0.140 & 0.200 & 0.170 & 0.220 & 0.218 \\
\hline Advanced degree & 0.070 & 0.046 & 0.084 & 0.065 & 0.066 & 0.068 \\
\hline Years of full-time work experience since age 18 & 18.117 & 10.568 & 18.135 & 12.813 & 19.623 & 15.009 \\
\hline Years of part-time work experience since age 18 & 1.276 & 3.198 & 1.756 & 3.603 & 1.552 & 3.863 \\
\hline Total years of work experience since age 18 & 19.392 & 13.766 & 19.892 & 16.416 & 21.175 & 18.871 \\
\hline Potential experience (age-educ-6) & 19.772 & 19.223 & 19.300 & 19.872 & 20.775 & 21.380 \\
\hline Age-18 & 20.487 & 19.884 & 20.602 & 21.092 & 22.239 & 22.997 \\
\hline Sample Size & 2938 & 2461 & 3021 & 2940 & 2439 & 2284 \\
\hline
\end{tabular}

Note: Means are weighted using PSID sampling weights. 
Table 2: Actual vs. Potential Experience in Wage Regressions (PSID)

\begin{tabular}{|c|c|c|c|c|c|c|}
\hline \multirow[t]{2}{*}{ A. Actual Experience Specification } & \multicolumn{3}{|c|}{ Women } & \multicolumn{3}{|c|}{ Men } \\
\hline & 1980 & 1990 & 1999 & 1980 & 1990 & 1999 \\
\hline \multirow[t]{2}{*}{ White } & $0.0933^{\star *}$ & $0.1176^{\star \star}$ & -0.0305 & $0.1089^{\star \star}$ & $0.1551^{\star \star}$ & $0.1815^{\star \star}$ \\
\hline & $(0.0256)$ & $(0.0246)$ & $(0.0293)$ & $(0.0257)$ & $(0.0277)$ & $(0.0319)$ \\
\hline \multirow[t]{2}{*}{ Years of schooling } & $0.0746^{\star *}$ & $0.0962^{* *}$ & $0.0864^{\star \star}$ & $0.0531^{\star *}$ & $0.0761^{\star \star}$ & $0.0666^{\star \star}$ \\
\hline & $(0.0064)$ & $(0.0071)$ & $(0.0086)$ & $(0.0047)$ & $(0.0062)$ & $(0.0076)$ \\
\hline \multirow[t]{2}{*}{ College degree (no advanced degree) } & 0.0278 & $0.0982^{\star *}$ & $0.1185^{\star *}$ & 0.0382 & $0.0918^{\star \star}$ & $0.1525^{\star *}$ \\
\hline & $(0.0371)$ & $(0.0355)$ & $(0.0397)$ & $(0.0304)$ & $(0.0325)$ & $(0.0378)$ \\
\hline \multirow[t]{2}{*}{ Advanced degree } & $0.2804^{\star *}$ & $0.2521 * \star$ & $0.2373^{\star \star}$ & 0.0592 & $0.1412^{\star \star}$ & $0.3025^{\star *}$ \\
\hline & $(0.0549)$ & $(0.0496)$ & $(0.0579)$ & $(0.0416)$ & $(0.0444)$ & $(0.0564)$ \\
\hline \multirow[t]{2}{*}{ Years of actual experience } & $0.0320 * \star$ & $0.0465^{\star \star}$ & $0.0417^{\star \star}$ & $0.0494^{\star \star}$ & $0.0532^{\star *}$ & $0.0511^{\star *}$ \\
\hline & $(0.0034)$ & $(0.0035)$ & $(0.0043)$ & $(0.0030)$ & $(0.0033)$ & $(0.0041)$ \\
\hline \multirow[t]{2}{*}{ Actual experience squared } & $-0.0006^{\star \star}$ & $-0.0008^{\star \star}$ & $-0.0006^{\star \star}$ & $-0.0008^{\star *}$ & $-0.0008^{\star \star}$ & $-0.0008^{\star *}$ \\
\hline & $(0.0001)$ & $(0.0001)$ & $(0.0001)$ & $(0.0001)$ & $(0.0001)$ & $(0.0001)$ \\
\hline \multirow[t]{2}{*}{ Constant } & $0.5645^{\star \star}$ & 0.0644 & $0.3761^{\star *}$ & $1.0452^{\star \star}$ & $0.4766^{\star \star}$ & $0.6283^{\star \star}$ \\
\hline & $(0.0809)$ & $(0.0925)$ & (0.1147) & $(0.0637)$ & $(0.0832)$ & (0.1015) \\
\hline R squared & 0.2235 & 0.3181 & 0.2486 & 0.2366 & 0.3107 & 0.2729 \\
\hline Sample size & 2461 & 2940 & 2284 & 2938 & 3021 & 2439 \\
\hline \multirow[t]{2}{*}{ B. Potential Experience Specification } & \multicolumn{3}{|c|}{ Women } & \multicolumn{3}{|c|}{ Men } \\
\hline & 1980 & 1990 & 1999 & 1980 & 1990 & 1999 \\
\hline \multirow[t]{2}{*}{ White } & $0.0822^{\star *}$ & $0.0987^{\star *}$ & -0.0254 & $0.1124^{\star \star}$ & $0.1594^{\star *}$ & $0.1899 * *$ \\
\hline & $(0.0262)$ & $(0.0255)$ & $(0.0300)$ & $(0.0257)$ & $(0.0278)$ & $(0.0319)$ \\
\hline \multirow[t]{2}{*}{ Years of schooling } & $0.0799 * \star$ & $0.1112^{\star \star}$ & $0.1005^{\star \star}$ & $0.0576^{\star \star}$ & 0.0864 ** & $0.0777^{\star \star}$ \\
\hline & $(0.0068)$ & $(0.0077)$ & $(0.0090)$ & $(0.0050)$ & $(0.0066)$ & $(0.0077)$ \\
\hline \multirow[t]{2}{*}{ College degree (no advanced degree) } & 0.0552 & $0.1018^{\star \star}$ & $0.1054^{\star *}$ & $0.0872^{\star \star}$ & $0.1334^{\star \star}$ & $0.1629^{\star *}$ \\
\hline & $(0.0380)$ & $(0.0371)$ & $(0.0406)$ & $(0.0308)$ & $(0.0332)$ & $(0.0380)$ \\
\hline \multirow[t]{2}{*}{ Advanced degree } & $0.3035^{\star \star}$ & $0.2719^{\star \star}$ & $0.2247^{* *}$ & $0.0900^{*}$ & $0.1406^{\star \star}$ & $0.2786^{\star \star}$ \\
\hline & $(0.0560)$ & $(0.0518)$ & $(0.0593)$ & $(0.0419)$ & $(0.0450)$ & $(0.0567)$ \\
\hline \multirow[t]{2}{*}{ Years of potential experience } & $0.0180^{\star *}$ & $0.0212^{\star *}$ & $0.0314^{\star *}$ & $0.0442^{\star \star}$ & $0.0490^{\star \star}$ & $0.0448^{* *}$ \\
\hline & $(0.0028)$ & $(0.0031)$ & $(0.0036)$ & $(0.0027)$ & $(0.0030)$ & $(0.0036)$ \\
\hline \multirow[t]{2}{*}{ Potential experience squared } & $-0.0003^{\star \star}$ & $-0.0003^{\star \star}$ & $-0.0005^{\star *}$ & $-0.0007^{\star \star}$ & $-0.0007^{\star \star}$ & $-0.0007^{\star \star}$ \\
\hline & $(0.0001)$ & $(0.0001)$ & $(0.0001)$ & $(0.0001)$ & $(0.0001)$ & $(0.0001)$ \\
\hline \multirow[t]{2}{*}{ Constant } & $0.5891^{\star \star}$ & 0.1046 & $0.3112^{*}$ & $1.0141^{\star \star}$ & $0.3921^{\star *}$ & $0.5405^{\star \star}$ \\
\hline & $(0.0879)$ & $(0.1016)$ & $(0.1221)$ & $(0.0655)$ & $(0.0867)$ & $(0.1037)$ \\
\hline R squared & 0.1958 & 0.2641 & 0.2128 & 0.2367 & 0.3033 & 0.2708 \\
\hline Sample size & 2461 & 2940 & 2284 & 2938 & 3021 & 2439 \\
\hline
\end{tabular}

$+p<0.10,{ }^{*} p<0.05,{ }^{*} p<0.01$ 
Table 3: Actual Full-Time and Part-Time Experience in Wage Regressions (PSID)

\begin{tabular}{|c|c|c|c|c|c|c|}
\hline & \multicolumn{3}{|c|}{ Women } & \multicolumn{3}{|c|}{ Men } \\
\hline & 1980 & 1990 & 1999 & 1980 & 1990 & 1999 \\
\hline \multirow[t]{2}{*}{ White } & $0.0997 * *$ & $0.1327^{* *}$ & -0.0062 & $0.1016^{\star \star}$ & $0.1506^{\star *}$ & $0.1794^{\star *}$ \\
\hline & $(0.0256)$ & $(0.0240)$ & $(0.0290)$ & $(0.0257)$ & $(0.0275)$ & $(0.0319)$ \\
\hline \multirow[t]{2}{*}{ Years of schooling } & $0.0749 * *$ & $0.0961^{* *}$ & $0.0865^{\star \star}$ & $0.0548^{\star *}$ & $0.0804^{\star *}$ & $0.0716^{\star *}$ \\
\hline & $(0.0064)$ & $(0.0070)$ & $(0.0085)$ & $(0.0047)$ & $(0.0062)$ & $(0.0076)$ \\
\hline \multirow[t]{2}{*}{ College degree (no advanced degree) } & 0.0446 & $0.1413^{* *}$ & $0.1493^{\star *}$ & $0.0672^{*}$ & $0.1479 * *$ & $0.1682^{\star *}$ \\
\hline & $(0.0372)$ & $(0.0348)$ & $(0.0393)$ & $(0.0309)$ & $(0.0331)$ & $(0.0383)$ \\
\hline \multirow[t]{2}{*}{ Advanced degree } & $0.2988^{\star *}$ & $0.2736^{\star *}$ & $0.2486^{\star \star}$ & $0.0852^{*}$ & $0.1708^{\star *}$ & $0.2924^{\star *}$ \\
\hline & $(0.0550)$ & $(0.0484)$ & $(0.0571)$ & $(0.0422)$ & $(0.0446)$ & $(0.0566)$ \\
\hline \multirow[t]{2}{*}{ Years of full-time work experience since age 18} & $0.0290 * *$ & $0.0508^{\star *}$ & $0.0421^{\star *}$ & $0.0470 * \star$ & $0.0485^{\star \star}$ & $0.0487^{\star *}$ \\
\hline & $(0.0030)$ & $(0.0031)$ & $(0.0037)$ & $(0.0028)$ & $(0.0030)$ & $(0.0037)$ \\
\hline \multirow[t]{2}{*}{ Full-time experience squared } & $-0.0005^{\star \star}$ & $-0.0009 * *$ & $-0.0007^{* *}$ & $-0.0008^{* *}$ & $-0.0007^{* *}$ & $-0.0008^{\star *}$ \\
\hline & $(0.0001)$ & $(0.0001)$ & $(0.0001)$ & $(0.0001)$ & $(0.0001)$ & $(0.0001)$ \\
\hline \multirow[t]{2}{*}{ Years of part-time work experience since age 18} & 0.0007 & $-0.0079 *$ & -0.0031 & 0.0021 & -0.0094 & -0.0055 \\
\hline & $(0.0044)$ & $(0.0040)$ & $(0.0051)$ & $(0.0066)$ & $(0.0061)$ & $(0.0100)$ \\
\hline \multirow[t]{2}{*}{ Part-time experience squared } & 0.0002 & $0.0005^{\star *}$ & 0.0002 & -0.0000 & $0.0007^{*}$ & 0.0012 \\
\hline & $(0.0002)$ & $(0.0002)$ & $(0.0002)$ & $(0.0004)$ & $(0.0003)$ & $(0.0009)$ \\
\hline \multirow[t]{2}{*}{ Constant } & $0.6218^{* *}$ & 0.1280 & $0.4385^{\star \star}$ & $1.0828^{\star *}$ & $0.5236^{\star *}$ & $0.6305^{\star *}$ \\
\hline & $(0.0802)$ & $(0.0894)$ & $(0.1115)$ & $(0.0630)$ & $(0.0820)$ & $(0.1014)$ \\
\hline R squared & 0.2265 & 0.3509 & 0.2698 & 0.2404 & 0.3189 & 0.2754 \\
\hline Sample Size & 2461 & 2940 & 2284 & 2938 & 3021 & 2439 \\
\hline
\end{tabular}

$+p<0.10,{ }^{*} p<0.05,{ }^{* \star} p<0.01$ 
Table 4: Unexplained Pay Gaps (PSID)

\section{A. Average Female Residual from Male Wage Equation}

\begin{tabular}{lccc}
\hline Specification & 1980 & 1990 & 1999 \\
\hline & & & \\
Potential Experience & -0.466 & -0.344 & -0.288 \\
Actual Experience & -0.389 & -0.274 & -0.260 \\
$\begin{array}{l}\text { Actual Full-time and Part-time Experience } \\
\quad \text { Without Break Time }\end{array}$ & & \\
$\quad$ With Break Time & -0.341 & -0.223 & -0.232 \\
\hline
\end{tabular}

B. Average Nonwhite Male Residual from White Male Wage Equation

\begin{tabular}{lccc}
\hline Specification & 1980 & 1990 & 1999 \\
\hline & & & \\
Potential Experience & -0.109 & -0.158 & -0.191 \\
Actual Experience & -0.107 & -0.154 & -0.182 \\
Actual Full-time and Part-time Experience & -0.098 & -0.149 & -0.180 \\
\hline
\end{tabular}

\section{Average Nonwhite Female Residual from White Female Wage} Equation

\begin{tabular}{lccc}
\hline Specification & 1980 & 1990 & 1999 \\
\hline & & & \\
Potential Experience & -0.079 & -0.100 & 0.023 \\
Actual Experience & -0.092 & -0.119 & 0.029 \\
Actual Full-time and Part-time Experience & -0.097 & -0.133 & 0.004 \\
\hline
\end{tabular}


Table 5: Alternate Measures of Work Experience, 1976 and 1985 PSID, Women Employed as Wage and Salary Workers in 1985 Who Were in the Panel from 1976-1985

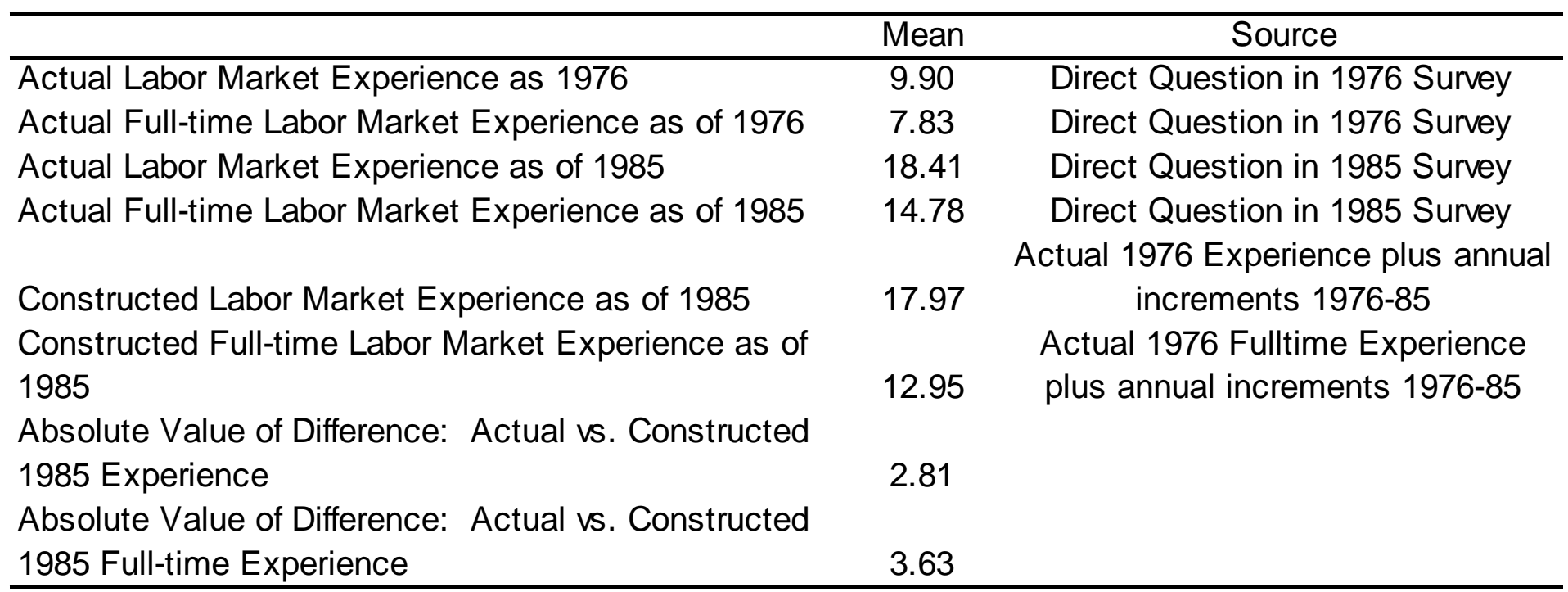

Note: Sample size is 1643. 
Table 6: Determinants of the Absolute Value of the Difference Between Actual and Constructed 1985 Work Experience for Women (PSID)

\begin{tabular}{lcccc}
\hline & $(1)$ & $(2)$ & $(3)$ & $(4)$ \\
\hline White & $-0.5865^{\star}$ & $-0.5854^{\star}$ & $-0.5863^{\star}$ & $-0.5852^{\star}$ \\
Age 1985 & $(0.2467)$ & $(0.2469)$ & $(0.2468)$ & $(0.2470)$ \\
& $0.1148^{\star \star}$ & $0.1146^{\star \star}$ & 0.1211 & 0.1199 \\
Age 1985 squared & $(0.0089)$ & $(0.0090)$ & $(0.0895)$ & $(0.0897)$ \\
Yrs of schooling & & & -0.0001 & -0.0001 \\
& & & $(0.0010)$ & $(0.0010)$ \\
College degree & $(0.0370)$ & $(0.0587)$ & $-0.0743^{\star}$ & -0.0846 \\
& & 0.0427 & $(0.0371)$ & $(0.0587)$ \\
Advanced degree & & $(0.3455)$ & & 0.0430 \\
Constant & & 0.1223 & & $(0.3456)$ \\
& & $(0.4392)$ & & 0.1214 \\
& & -0.6148 & -0.8774 & $(0.4396)$ \\
Sample Size & -0.7449 & $(0.8811)$ & $(1.9913)$ & -0.7286 \\
& $(0.6801)$ & & & $(2.0780)$ \\
\end{tabular}

$+p<0.10,{ }^{*} p<0.05,{ }^{* *} p<0.01$ 
Table 7: Wage Effects of Alternative Experience Measures for Women (PSID)

\begin{tabular}{|c|c|c|c|c|}
\hline & \multicolumn{3}{|c|}{ A. OLS } & \multirow{2}{*}{$\begin{array}{c}\text { B. IV } \\
(4)\end{array}$} \\
\hline & $(1)$ & $(2)$ & (3) & \\
\hline \multirow[t]{2}{*}{ White } & $0.0763^{*}$ & $0.0977^{\star \star}$ & $0.0938^{\star \star}$ & $0.1069^{\star \star}$ \\
\hline & $(0.0358)$ & $(0.0349)$ & $(0.0347)$ & $(0.0351)$ \\
\hline \multirow[t]{2}{*}{ Years of schooling } & $0.0808^{\star \star}$ & $0.0751^{\star \star}$ & $0.0777^{\star *}$ & $0.0773^{\star *}$ \\
\hline & $(0.0090)$ & $(0.0082)$ & $(0.0081)$ & $(0.0084)$ \\
\hline \multirow[t]{2}{*}{ College degree } & 0.0668 & 0.0696 & 0.0521 & 0.0613 \\
\hline & $(0.0506)$ & $(0.0487)$ & $(0.0483)$ & $(0.0490)$ \\
\hline \multirow[t]{2}{*}{ Advanced degree } & $0.3698^{\star *}$ & $0.3422^{\star *}$ & $0.3216^{\star \star}$ & $0.3200^{* \star}$ \\
\hline & $(0.0641)$ & $(0.0620)$ & $(0.0615)$ & $(0.0624)$ \\
\hline \multirow[t]{2}{*}{ Potential experience } & 0.0020 & & & \\
\hline & $(0.0066)$ & & & \\
\hline \multirow[t]{2}{*}{ Potential experience squared } & 0.0000 & & & \\
\hline & $(0.0001)$ & & & \\
\hline \multirow[t]{2}{*}{1985 survey experience } & & $0.0439 * \star$ & & $0.0545^{\star \star}$ \\
\hline & & $(0.0052)$ & & $(0.0070)$ \\
\hline \multirow[t]{2}{*}{1985 survey experience squared } & & $-0.0008^{\star *}$ & & $-0.0009 * *$ \\
\hline & & $(0.0001)$ & & $(0.0002)$ \\
\hline \multirow[t]{2}{*}{1985 constructed experience } & & & $0.0495^{\star *}$ & \\
\hline & & & $(0.0059)$ & \\
\hline \multirow[t]{2}{*}{1985 constructed experience squared } & & & $-0.0008^{\star *}$ & \\
\hline & & & $(0.0001)$ & \\
\hline \multirow[t]{2}{*}{ Constant } & $0.7148^{\star \star}$ & $0.3546^{\star *}$ & $0.2445^{\star}$ & 0.1883 \\
\hline & $(0.1360)$ & $(0.1112)$ & $(0.1134)$ & $(0.1168)$ \\
\hline Sample Size & 1643 & 1643 & 1643 & 1643 \\
\hline
\end{tabular}

Notes: Constructed Experience is computed by adding annual 1976-85 increments to the 1976 value. In the instrumental variables model, 1985 constructed experience and its square are used as instruments for the 1985 survey experience and 1985 survey experience squared variables. Includes women employed as wage and salary workers as of 1985 who are in the panel 1976-85.

$+p<0.10,{ }^{*} p<0.05,{ }^{* *} p<0.01$ 
Table 8: Further Results--Wage Effects of Alternative Experience Measures for Women (PSID)

\begin{tabular}{|c|c|c|c|}
\hline & \multicolumn{2}{|c|}{ A. OLS } & \multirow{2}{*}{$\frac{\text { B. IV }}{(3)}$} \\
\hline & $(1)$ & $(2)$ & \\
\hline \multirow[t]{2}{*}{ White } & $0.1176^{\star \star}$ & $0.1133^{\star *}$ & $0.1471^{\star \star}$ \\
\hline & $(0.0350)$ & $(0.0342)$ & $(0.0379)$ \\
\hline \multirow[t]{2}{*}{ Years of schooling } & $0.0742^{\star \star}$ & $0.0735^{\star \star}$ & $0.0845^{\star \star}$ \\
\hline & $(0.0083)$ & $(0.0080)$ & $(0.0100)$ \\
\hline \multirow[t]{2}{*}{ College degree } & $0.1051^{*}$ & $0.1252^{\star \star}$ & $0.1227^{*}$ \\
\hline & $(0.0489)$ & $(0.0483)$ & $(0.0537)$ \\
\hline \multirow[t]{2}{*}{ Advanced degree } & $0.3528^{\star \star}$ & $0.3887^{\star \star}$ & $0.3538^{* *}$ \\
\hline & $(0.0617)$ & $(0.0612)$ & $(0.0666)$ \\
\hline \multirow[t]{2}{*}{1985 survey full-time experience } & $0.0335^{\star \star}$ & & $0.0376^{\star \star}$ \\
\hline & $(0.0042)$ & & $(0.0067)$ \\
\hline \multirow[t]{2}{*}{1985 survey full-time experience squared } & $-0.0006^{\star \star}$ & & $-0.0007^{\star \star}$ \\
\hline & $(0.0001)$ & & $(0.0002)$ \\
\hline \multirow[t]{2}{*}{1985 survey part-time experience } & -0.0045 & & $-0.0721^{\star \star}$ \\
\hline & $(0.0050)$ & & $(0.0223)$ \\
\hline \multirow[t]{2}{*}{1985 survey part-time experience squared } & $0.0004+$ & & $0.0034^{\star *}$ \\
\hline & $(0.0002)$ & & $(0.0010)$ \\
\hline \multirow[t]{2}{*}{1985 constructed full-time experience } & & $0.0368^{\star \star}$ & \\
\hline & & $(0.0043)$ & \\
\hline \multirow[t]{2}{*}{1985 constructed full-time experience squared } & & $-0.0007^{\star \star}$ & \\
\hline & & $(0.0001)$ & \\
\hline \multirow[t]{2}{*}{1985 constructed part-time experience } & & $-0.0185^{\star \star}$ & \\
\hline & & $(0.0061)$ & \\
\hline \multirow[t]{2}{*}{1985 constructed part-time experience squared } & & $0.0010^{\star \star}$ & \\
\hline & & $(0.0003)$ & \\
\hline \multirow[t]{2}{*}{ Constant } & $0.5030^{\star \star}$ & $0.5633^{\star *}$ & $0.4158^{\star *}$ \\
\hline & $(0.1080)$ & $(0.1085)$ & $(0.1213)$ \\
\hline Sample size & 1643 & 1643 & 1643 \\
\hline
\end{tabular}

Notes: Constructed Experience is computed by adding annual 1976-85 increments to the 1976 value. In the instrumental variables model, 1985 full-time and part-time constructed experience and their squares are used as instruments for the

corresponding 1985 survey experience variables. Includes women employed as wage and salary workers as of 1985 who are in the panel 1976-85.

$+p<0.10,{ }^{*} p<0.05,{ }^{* *} p<0.01$ 
Table 9: Descriptive Statistics, PDII Sample, August 2008

\begin{tabular}{|c|c|c|c|c|}
\hline \multirow{3}{*}{ A. Men } & \multicolumn{2}{|c|}{ Full Sample } & \multicolumn{2}{|c|}{ Wage Sample } \\
\hline & Mean & Std. Dev & Mean & Std. Dev \\
\hline & \multicolumn{2}{|c|}{$n=1015$} & \multicolumn{2}{|c|}{$\mathrm{n}=704$} \\
\hline Log hourly wage & & & 3.132 & 0.630 \\
\hline Age & 41.178 & 11.751 & 40.898 & 11.710 \\
\hline Educ (years) & 13.840 & 3.044 & 13.785 & 2.885 \\
\hline Potential experience & 21.343 & 11.808 & 21.113 & 11.623 \\
\hline Black & 0.074 & 0.262 & 0.074 & 0.261 \\
\hline Hispanic & 0.170 & 0.376 & 0.174 & 0.379 \\
\hline Asian & 0.028 & 0.165 & 0.031 & 0.174 \\
\hline Otherrace & 0.042 & 0.201 & 0.045 & 0.208 \\
\hline Actual experience, after resurvey & 22.171 & 11.802 & 21.922 & 11.724 \\
\hline Actual experience, before resurvey & 22.320 & 11.883 & 22.084 & 11.789 \\
\hline Actual experience, after resurvey, & & & & \\
\hline constrained to start at age 18 & 21.919 & 11.747 & 21.715 & 11.670 \\
\hline Actual full-time experience, after resurvey & 20.087 & 11.972 & 19.902 & 11.947 \\
\hline Actual part-time experience, after resurvey & 2.083 & 3.457 & 2.020 & 3.422 \\
\hline Actual full-time experience, before resurvey & 20.157 & 12.014 & 19.985 & 11.963 \\
\hline Actual part-time experience, before resurvey & 2.164 & 3.648 & 2.104 & 3.658 \\
\hline $\begin{array}{l}\text { Actual full-time experience, after resurvey, } \\
\text { constrained to start at age } 18\end{array}$ & 19.919 & 11.945 & 19.759 & 11.925 \\
\hline $\begin{array}{l}\text { Actual part-time experience, after resurvey, } \\
\text { constrained to start at age } 18\end{array}$ & 2.001 & 3.371 & 1.956 & 3.327 \\
\hline \multirow[t]{2}{*}{ B. Women } & Mean & Std. Dev & Mean & Std. Dev \\
\hline & \multicolumn{2}{|c|}{$n=1213$} & \multicolumn{2}{|c|}{$\mathrm{n}=807$} \\
\hline Log hourly wage & & & 2.843 & 0.625 \\
\hline Age & 41.739 & 11.674 & 41.297 & 11.694 \\
\hline Educ (years) & 14.081 & 2.623 & 14.083 & 2.655 \\
\hline Potential experience & 21.658 & 11.854 & 21.214 & 11.863 \\
\hline Black & 0.104 & 0.305 & 0.107 & 0.310 \\
\hline Hispanic & 0.125 & 0.331 & 0.136 & 0.343 \\
\hline Asian & 0.038 & 0.192 & 0.028 & 0.164 \\
\hline Otherrace & 0.037 & 0.190 & 0.046 & 0.209 \\
\hline Actual experience, after resurvey & 20.813 & 11.197 & 20.485 & 11.242 \\
\hline Actual experience, before resurvey & 20.900 & 11.251 & 20.600 & 11.312 \\
\hline $\begin{array}{l}\text { Actual experience, after resurvey, } \\
\text { constrained to start at age } 18\end{array}$ & 20.477 & 11.042 & 20.278 & 11.112 \\
\hline Actual full-time experience, after resurvey & 17.206 & 11.236 & 17.072 & 11.301 \\
\hline Actual part-time experience, after resurvey & 3.606 & 4.838 & 3.413 & 4.659 \\
\hline Actual full-time experience, before resurvey & 17.254 & 11.267 & 17.128 & 11.334 \\
\hline Actual part-time experience, before resurvey & 3.646 & 4.905 & 3.472 & 4.754 \\
\hline $\begin{array}{l}\text { Actual full-time experience, after resurvey, } \\
\text { constrained to start at age } 18\end{array}$ & 17.005 & 11.122 & 16.958 & 11.214 \\
\hline $\begin{array}{l}\text { Actual part-time experience, after resurvey, } \\
\text { constrained to start at age } 18\end{array}$ & 3.472 & 4.751 & 3.320 & 4.600 \\
\hline
\end{tabular}


Table 10: Average Female Residual from Male Wage Equation, Various Specifications (PDII Sample)

\begin{tabular}{lcc}
\hline & \multicolumn{2}{c}{ Average Female Residual } \\
\cline { 2 - 3 } Specification & All Workers & Married Workers Only \\
\hline Raw Gender Pay Gap & -0.289 & -0.373 \\
Potential Experience & -0.319 & -0.410 \\
Aggregate Actual Experience, After Resurvey & -0.303 & -0.396 \\
Aggregate Actual Experience, Before Resurvey & -0.304 & -0.397 \\
Aggregate Actual Experience, After Resurvey, & & \\
constrained to start at age 18 & -0.304 & -0.396 \\
Full- and Part-Time Actual Experience, After & & \\
Resurvey & -0.289 & -0.390 \\
Full- and Part-Time Actual Experience, Before & & -0.385 \\
Resurvey & -0.287 & \\
Full- and Part-Time Actual Experience, After & & -0.387 \\
Resurvey, constrained to start at age 18 & -0.289 & \\
Full- and Part-Time Actual Experience, and & & -0.394 \\
Break Time, After Resurvey, constrained to start & & -0.271 \\
at age 18 & &
\end{tabular}

Note: potential and actual experience variables are quadratic. 
Table 11: Actual vs. Proxy Responses, Married Individuals Age 18-65, PDII Survey

\begin{tabular}{lcccc}
\hline & \multicolumn{2}{c}{ Men } & \multicolumn{2}{c}{ Women } \\
\cline { 2 - 5 } & Proxy & Self & Proxy & Self \\
\hline Age & 42.422 & 44.011 & 44.049 & 43.557 \\
Educ (years) & 13.893 & 14.161 & 14.808 & 14.452 \\
Potential experience & 22.334 & 23.856 & 23.198 & 23.105 \\
Black & 0.060 & 0.054 & 0.050 & 0.070 \\
Hispanic & 0.024 & 0.156 & 0.125 & 0.094 \\
Asian & 0.000 & 0.031 & 0.000 & 0.045 \\
Otherrace & 0.000 & 0.036 & 0.105 & 0.019 \\
Actual experience, before resurvey & 23.218 & 25.220 & 21.330 & 22.204 \\
Actual experience, after resurvey, & & & & \\
constrained to start at age 18 & 23.036 & 24.874 & 21.316 & 21.912 \\
Actual full-time experience, before resurvey & 21.542 & 22.991 & 18.850 & 17.994 \\
Actual part-time experience, before resurvey & 1.677 & 2.229 & 2.480 & 4.210 \\
Actual full-time experience, after resurvey, & & & & \\
constrained to start at age 18 & 21.471 & 22.826 & 18.850 & 17.845 \\
Actual part-time experience, after resurvey, & & & & \\
constrained to start at age 18 & 1.565 & 2.048 & 2.466 & 4.067 \\
Sample size & 48 & 687 & 51 & 679 \\
\hline
\end{tabular}

Note: "Proxy" men are husbands of women who were asked to provide information about another adult in the household, with an analogous definition for proxy women. "Self" denotes married respondents providing their own data. 
Table A1: Actual Full-Time and Part-Time Experience in Wage Regressions with Break Time Dummies (PSID)

\begin{tabular}{|c|c|c|c|c|c|c|}
\hline & \multicolumn{3}{|c|}{ Women } & \multicolumn{3}{|c|}{ Men } \\
\hline & 1980 & 1990 & 1999 & 1980 & 1990 & 1999 \\
\hline \multirow[t]{2}{*}{ White } & $0.1072^{\star \star}$ & $0.1351^{\star *}$ & 0.0006 & $0.1008^{\star *}$ & $0.1452^{\star \star}$ & $0.1782^{\star \star}$ \\
\hline & $(0.0256)$ & $(0.0240)$ & $(0.0289)$ & $(0.0257)$ & $(0.0274)$ & $(0.0321)$ \\
\hline \multirow[t]{2}{*}{ Years of schooling } & $0.0684^{\star *}$ & $0.0816^{\star *}$ & $0.0651^{\star *}$ & $0.0552^{\star *}$ & $0.0564^{\star *}$ & $0.0676^{\star \star}$ \\
\hline & $(0.0069)$ & $(0.0074)$ & $(0.0094)$ & $(0.0059)$ & $(0.0080)$ & $(0.0093)$ \\
\hline \multirow[t]{2}{*}{ College degree (no advanced degree) } & 0.0517 & $0.1517^{\star \star}$ & $0.1736^{* *}$ & $0.0639^{*}$ & $0.2065^{\star \star}$ & $0.1727^{\star \star}$ \\
\hline & $(0.0372)$ & $(0.0348)$ & $(0.0393)$ & $(0.0322)$ & $(0.0356)$ & $(0.0397)$ \\
\hline \multirow[t]{2}{*}{ Advanced degree } & $0.3172^{\star \star}$ & $0.3023^{\star *}$ & $0.2962^{\star *}$ & $0.0822+$ & $0.2675^{\star \star}$ & $0.3028^{\star \star}$ \\
\hline & $(0.0552)$ & $(0.0486)$ & $(0.0574)$ & $(0.0445)$ & $(0.0492)$ & $(0.0596)$ \\
\hline \multirow[t]{2}{*}{ Years of full-time work experience since age 18} & $0.0297^{\star \star}$ & $0.0515^{\star \star}$ & $0.0442^{\star *}$ & $0.0470 * *$ & $0.0484^{\star *}$ & $0.0491^{\star *}$ \\
\hline & $(0.0031)$ & $(0.0031)$ & $(0.0037)$ & $(0.0028)$ & $(0.0029)$ & $(0.0038)$ \\
\hline \multirow[t]{2}{*}{ Full-time experience squared } & $-0.0005^{\star \star}$ & $-0.0010^{\star *}$ & $-0.0007^{\star *}$ & $-0.0008^{\star \star}$ & $-0.0007^{\star \star}$ & $-0.0008^{\star \star}$ \\
\hline & $(0.0001)$ & $(0.0001)$ & $(0.0001)$ & $(0.0001)$ & $(0.0001)$ & $(0.0001)$ \\
\hline \multirow[t]{2}{*}{ Years of part-time work experience since age 18} & 0.0037 & -0.0056 & 0.0028 & 0.0018 & -0.0086 & -0.0045 \\
\hline & $(0.0045)$ & $(0.0040)$ & $(0.0052)$ & $(0.0067)$ & $(0.0061)$ & $(0.0101)$ \\
\hline \multirow[t]{2}{*}{ Part-time experience squared } & 0.0000 & $0.0005^{\star \star}$ & 0.0001 & 0.0000 & $0.0007^{*}$ & 0.0011 \\
\hline & $(0.0002)$ & $(0.0002)$ & $(0.0002)$ & $(0.0004)$ & $(0.0003)$ & $(0.0010)$ \\
\hline \multirow[t]{2}{*}{ Break time $>=1$ and $<2$ yrs } & 0.0518 & $-0.1613^{\star \star}$ & $-0.0706+$ & -0.0049 & $-0.0896^{\star \star}$ & -0.0365 \\
\hline & $(0.0370)$ & $(0.0337)$ & $(0.0376)$ & $(0.0291)$ & $(0.0310)$ & $(0.0323)$ \\
\hline \multirow[t]{2}{*}{ Break time $>=2 \&<3$ years } & -0.0359 & $-0.0918^{*}$ & $-0.1477^{\star \star}$ & -0.0403 & $-0.1027^{\star \star}$ & -0.0185 \\
\hline & $(0.0407)$ & $(0.0398)$ & $(0.0490)$ & $(0.0324)$ & $(0.0380)$ & $(0.0492)$ \\
\hline \multirow[t]{2}{*}{ Break time $>=3 \mathrm{yrs}$} & $-0.0571^{*}$ & $-0.1158^{\star \star}$ & $-0.1440^{* *}$ & 0.0063 & $-0.1686^{\star \star}$ & -0.0237 \\
\hline & $(0.0230)$ & $(0.0208)$ & $(0.0281)$ & $(0.0286)$ & $(0.0388)$ & $(0.0455)$ \\
\hline \multirow[t]{2}{*}{ Constant } & $0.7113^{\star \star}$ & $0.3643^{\star \star}$ & $0.7488^{\star \star}$ & $1.0816^{\star *}$ & $0.8601^{\star *}$ & $0.6881^{\star \star}$ \\
\hline & $(0.0885)$ & $(0.0973)$ & $(0.1263)$ & $(0.0806)$ & $(0.1081)$ & $(0.1262)$ \\
\hline R squared & 0.2304 & 0.3602 & 0.2791 & 0.2409 & 0.3242 & 0.2758 \\
\hline Sample Size & 2461 & 2940 & 2284 & 2938 & 3021 & 2439 \\
\hline
\end{tabular}

$+p<0.10,{ }^{*} p<0.05,{ }^{* *} p<0.01$ 
Table A2: Goodness of Fit and Residual Inequality, Alternative Specifications for Women (PSID)

\begin{tabular}{|c|c|c|c|c|}
\hline & 1980 & 1990 & 1999 & $\begin{array}{l}\text { Change: } \\
\text { 1999-1980 }\end{array}$ \\
\hline \multicolumn{5}{|l|}{ Specification } \\
\hline \multicolumn{5}{|l|}{ Potential Experience } \\
\hline R Squared & 0.196 & 0.264 & 0.213 & 0.017 \\
\hline Adj. R squared & 0.194 & 0.263 & 0.211 & 0.017 \\
\hline Residual Variance & 0.212 & 0.252 & 0.280 & 0.068 \\
\hline \multicolumn{5}{|l|}{ Actual Total Experience } \\
\hline R Squared & 0.224 & 0.318 & 0.249 & 0.025 \\
\hline Adj. R squared & 0.222 & 0.317 & 0.247 & 0.025 \\
\hline Residual Variance & 0.204 & 0.233 & 0.267 & 0.063 \\
\hline \multicolumn{5}{|c|}{ Actual Full-Time and Part-Time } \\
\hline \multicolumn{5}{|c|}{ Experience Disaggregated } \\
\hline R Squared & 0.227 & 0.351 & 0.270 & 0.043 \\
\hline Adj. R squared & 0.224 & 0.349 & 0.267 & 0.043 \\
\hline Residual Variance & 0.204 & 0.222 & 0.260 & 0.056 \\
\hline \multicolumn{5}{|c|}{$\begin{array}{l}\text { Potential Experience, Actual Full-Time } \\
\text { and Part-Time Experience Disaggregated }\end{array}$} \\
\hline R Squared & 0.229 & 0.357 & 0.277 & 0.048 \\
\hline Adj. R squared & 0.226 & 0.355 & 0.274 & 0.048 \\
\hline Residual Variance & 0.203 & 0.220 & 0.257 & 0.054 \\
\hline
\end{tabular}

Controls include: race, years of schooling, and dummies for college and advanced degrees. 
Table A3: Selected Wage Regression Results, PDII Survey Data, All Workers

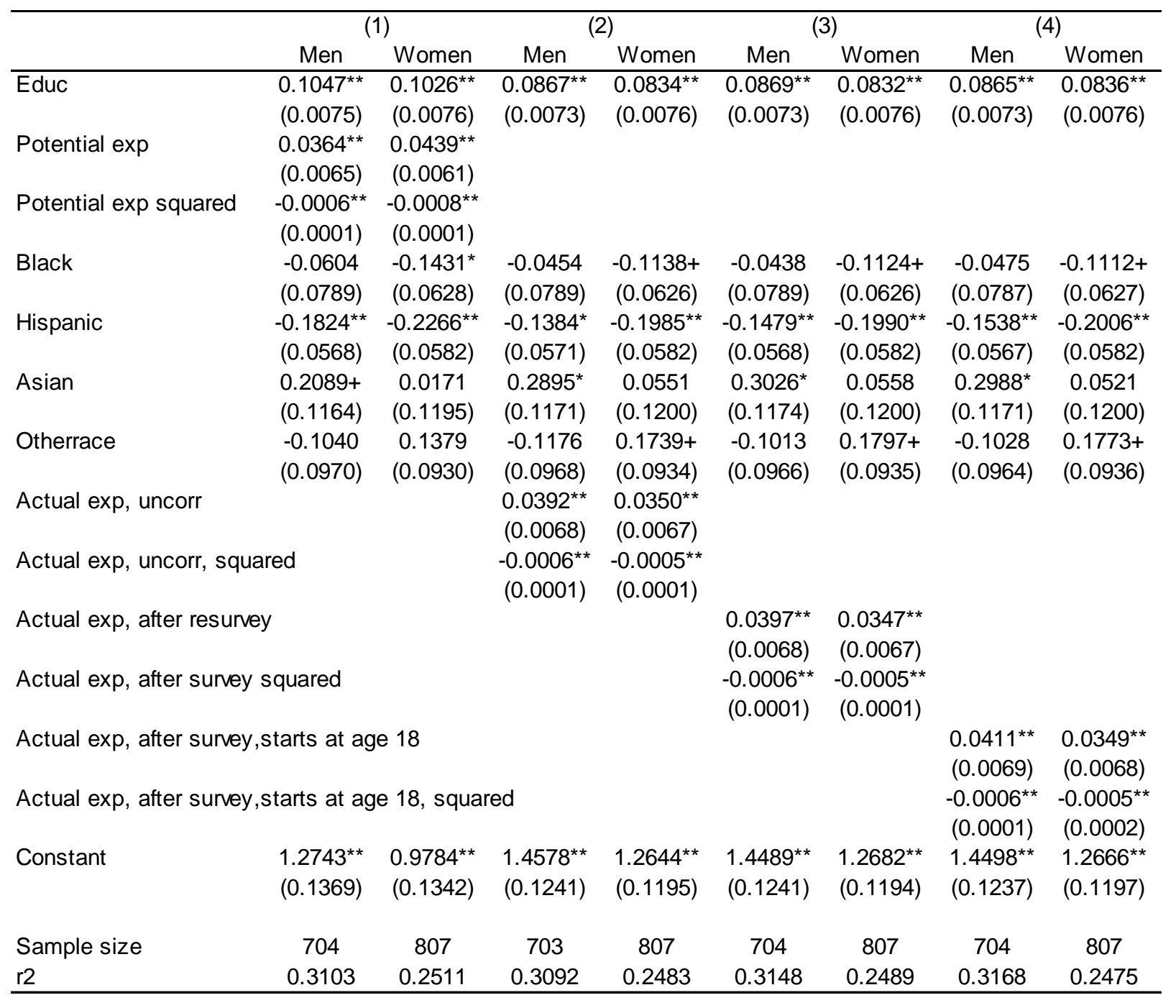

$+p<0.10,{ }^{*} p<0.05, * * p<0.01$ 
Table A3 (ctd): Selected Wage Regression Results, PDII Survey Data, All Workers

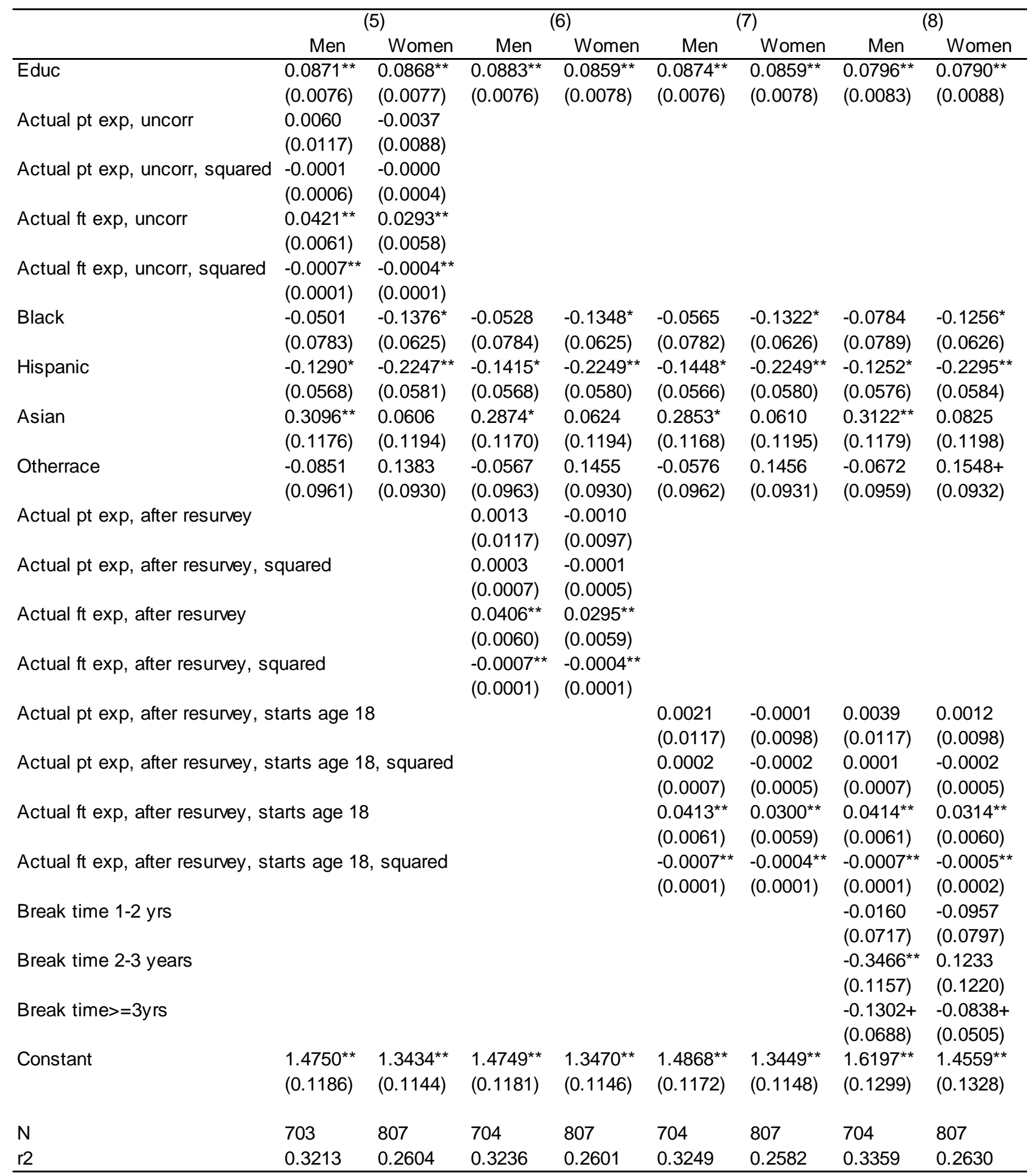

$+p<0.10,{ }^{*} p<0.05,{ }^{* \star} p<0.01$ 
Table A4 Goodness of Fit and Residual Inequality, Alternative Specifications for Women (PDII Survey)

\begin{tabular}{|c|c|c|c|}
\hline $\begin{array}{l}\text { Full Wage Sample }(n=807) \\
\text { Specification }\end{array}$ & & $\begin{array}{l}\text { Sample with Valid Tenure Observations }(n=704) \\
\text { Specification }\end{array}$ & \\
\hline Potential Experience & & Potential Experience & \\
\hline R Squared & 0.251 & R Squared & 0.274 \\
\hline Adj. R squared & 0.245 & Adj. R squared & 0.267 \\
\hline Residual Variance & 0.296 & Residual Variance & 0.258 \\
\hline \multicolumn{4}{|l|}{ Actual Total Experience, Constrained to } \\
\hline Start at Age 18 & & Potential Experience and Tenure & \\
\hline R Squared & 0.248 & R Squared & 0.323 \\
\hline Adj. R squared & 0.241 & Adj. R squared & 0.314 \\
\hline Residual Variance & 0.297 & Residual Variance & 0.242 \\
\hline Actual Full-Time and Part-Time & & Potential Experience, Tenure, Actual Full-Time and & \\
\hline Experience Disaggregated, Constrained to & & Part-Time Experience Disaggregated, Constrained to & \\
\hline Start at Age 18 & & Start at Age 18 & \\
\hline R Squared & 0.258 & R Squared & 0.351 \\
\hline Adj. R squared & 0.250 & Adj. R squared & 0.334 \\
\hline Residual Variance & 0.293 & Residual Variance & 0.233 \\
\hline \multicolumn{4}{|l|}{$\begin{array}{l}\text { Potential Experience, Actual Full-Time } \\
\text { and Part-Time Experience Disaggregated, } \\
\text { Constrained to Start at Age } 18\end{array}$} \\
\hline R Squared & 0.286 & & \\
\hline Adj. R squared & 0.276 & & \\
\hline Residual Variance & 0.283 & & \\
\hline
\end{tabular}

Controls include: race and years of schooling. All potential experience, actual experience and tenure variables are quadratic. 
Table A5 : Selected Additional Wage Regression Results for Women, PDII Survey Data

\begin{tabular}{|c|c|c|c|}
\hline & \multirow{2}{*}{$\begin{array}{c}\text { All Workers } \\
\text { (1) }\end{array}$} & \multicolumn{2}{|c|}{ Workers with Valid Tenure Observations } \\
\hline & & $(2)$ & (3) \\
\hline \multirow[t]{2}{*}{ Educ } & $0.0866^{\star \star}$ & $0.0882^{\star \star}$ & $0.0808^{\star \star}$ \\
\hline & $(0.0095)$ & $(0.0096)$ & $(0.0095)$ \\
\hline \multirow[t]{2}{*}{ Potential exp } & $0.0305^{\star *}$ & $0.0228^{*}$ & $0.0177+$ \\
\hline & $(0.0090)$ & $(0.0094)$ & $(0.0092)$ \\
\hline \multirow[t]{2}{*}{ Potential exp squared } & $-0.0009 * *$ & $-0.0007^{* *}$ & $-0.0007^{\star *}$ \\
\hline & $(0.0002)$ & $(0.0002)$ & $(0.0002)$ \\
\hline \multirow[t]{2}{*}{ Actual pt exp, after resurvey, starts age 18} & 0.0011 & 0.0008 & 0.0005 \\
\hline & $(0.0106)$ & $(0.0106)$ & $(0.0103)$ \\
\hline \multirow[t]{2}{*}{ Actual pt exp, after resurvey, starts age 18 , squared } & 0.0002 & 0.0002 & 0.0001 \\
\hline & $(0.0005)$ & $(0.0005)$ & $(0.0005)$ \\
\hline \multirow[t]{2}{*}{ Actual ft exp, after resurvey, starts age 18} & 0.0143 & $0.0182+$ & $0.0162+$ \\
\hline & $(0.0091)$ & $(0.0095)$ & $(0.0093)$ \\
\hline \multirow[t]{2}{*}{ Actual ft exp, after resurvey, starts age 18 , squared } & 0.0001 & 0.0001 & 0.0000 \\
\hline & $(0.0002)$ & $(0.0002)$ & $(0.0002)$ \\
\hline \multirow[t]{2}{*}{ Black } & $-0.1650^{\star \star}$ & $-0.1776^{\star *}$ & $-0.1847^{\star *}$ \\
\hline & $(0.0619)$ & $(0.0609)$ & $(0.0594)$ \\
\hline \multirow[t]{2}{*}{ Hispanic } & $-0.2498^{\star *}$ & $-0.2457^{* *}$ & $-0.2305^{\star \star}$ \\
\hline & $(0.0573)$ & $(0.0562)$ & $(0.0549)$ \\
\hline \multirow[t]{2}{*}{ Asian } & 0.0563 & 0.1304 & 0.1475 \\
\hline & $(0.1178)$ & $(0.1199)$ & $(0.1172)$ \\
\hline \multirow[t]{2}{*}{ Otherrace } & 0.1233 & 0.0906 & 0.0955 \\
\hline & $(0.0916)$ & $(0.0984)$ & $(0.0960)$ \\
\hline \multirow[t]{2}{*}{ Tenure } & & & $0.0234^{\star *}$ \\
\hline & & & $(0.0071)$ \\
\hline \multirow[t]{2}{*}{ Tenure squared } & & & -0.0003 \\
\hline & & & $(0.0002)$ \\
\hline \multirow[t]{2}{*}{ Constant } & $1.2163^{\star *}$ & $1.2312^{\star *}$ & $1.3214^{\star \star}$ \\
\hline & $(0.1482)$ & $(0.1510)$ & $(0.1484)$ \\
\hline $\mathrm{N}$ & 807 & 704 & 704 \\
\hline r2 & 0.2855 & 0.3164 & 0.3510 \\
\hline
\end{tabular}

$+p<0.10,{ }^{\star} p<0.05,{ }^{* *} p<0.01$ 